— 総 説—

哺乳動物における体外受精

丹。羽晧 二

京都大学農学部，京都市 606

\title{
Mammalian Fertilization In Vitro
}

\author{
Koji Nrwa \\ Department of Animal Science, College of Agriculture, \\ Kyoto University, Kyoto 606
}

\section{はじめに}

精子が卯子に侵入する前心, 雌性生殖器道内の精子に 怯 2 つ連続的な变化肪誘起される.1つ性理学的な いし生化学的な変化と考えられる受精能獲得（sperm capacitation $)^{1,2)}$ で㘯り，他の 1 つ模段階での微細な 形態的变化 (先体反応: acrosome reaction) ${ }^{3,4)}$ である. 体内での受精の研究に基づくこれらの現象の発見は，体 外受精成立のた如必要な条件として大きな示唆壳与兄 た. 事実，上くに受精能獲得現象の発見の 3 年後 (1954 年）には，交配後一定時間経過した雌ウサギの子宮から 回収した精子を用いて, 細胞形態学的見地から確実と思 われる体外受精の成功例がウサギで初好報告され さらに1959年には体外受精卵堂受容雌ウサギに移殖して 正常な産子汃得られた ${ }^{7}$. その後, 哺乳動物の体外受精

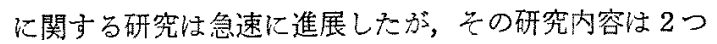
に分けて考えることができる.1つは種々の動物種炕お いて体外受精そのものの可能性它検討することである. この場合，何らかの方法で一旦成功寸れば，より安定し た受精弯の得られる技術の開発が容易となる。 もう一つ は，上記の内容含む研究の進展と表裏索なすものであ るが，受精の機序を解明するための研究手段として体外 受精技術を応用するすのである。最近，この種の研究領 域少飛躍的に膨張し, 多岐にるたる受精の機序も徐々に 明ら汃にされている.しかし，精子の受精能獲得 ${ }^{8-26) や ~}$ 先体反応11,15-17,19,20,24,27-30) の機序と受精における意義お よび精子の卵子への侵入機序, 16-19,26,37, 30) についてはす
でに多数のすぐれた総説が発表されているので，ここで はこれらの内容についての論議注最少限度にとどめた い. 体外受精に関する総説 ${ }^{17,32-43)}$ や一般的な解説記 事 ${ }^{44-57)}$ についても内外に推いて多数発表されているが， 本稿では，とくに動物種ごとの特徵を明確にしながら， 各諭的に体外受精技術の発展についてのこれ安での研究 成果を概観してみたい。

\section{I. 実験用小哺乳動物の体外受精}

ウサギ ${ }^{32-34,87,43,55)}$

形態学的江雅実な証拠のある体外受精の成功例が得ら れた最初の動物種であるが5,6)，精子の受精能獲得を体外 で誘起させる方法は長い間見出されなかった。したがっ て初期のほとえどの研究では, 交配政の子宮内で受精能 獲得它誘起させた精子（子宮精子）が用いられている5一 7,58-64). この場合，交配後 12 20 時間の範囲で 2 時間お きに回収した精子による体外受精菜 (93〜100\%) に有意

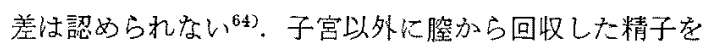
用いてむ体外受精は可能であり ${ }^{64-67)}$ ，最も高い受精率は 交配後 12〜14 時間で 回収した精子によって得られてい る ${ }^{64)}$. 体外での精子の受精能獲得誘起の試みこして, 子 宮液古るいは $\beta$-amylase ${ }^{68)}$, 好酸性白血球 ${ }^{69}, \beta$-glucronidase $^{70)}$, cyclic AMPやヒト卵胞液 ${ }^{71)}$ の存在下での 成功例が報告されているが，何れも確実な証抛恃示され ていない(37). さらに，センダイ virus ${ }^{72)}$ や子宮液73) の存 在下，失たは複雑組成からなる合成培地 ${ }^{74)}$ 内で処理さ れた精栄上体精子による体外受精の成功例が報告されて 


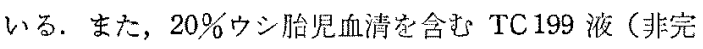

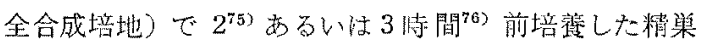
上体精子仁よる早期（それぞれ3時間以䧁战よび 1 洔間

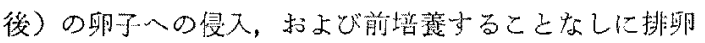
卵子に授精された射出精子に上万体外受精77,781が郝告さ れているが，これらの研究結果は何れも追試化よる確認 がなされていない, cyclic AMP $\left(10^{-6} \mathrm{M}\right), \mathrm{Ca}^{2+}(2.5 \times$ $\left.10^{-3} \mathrm{M}\right)$ および ionophore A 23187 を含屯培地で前培盖 した射出精子による体外受精の成功例も報告されている が99)，この場合，用いた卵子が裸化されていたのかどう か，さらに授精後の精子侵入時期について子明確な記載 がないので，前培養中に精子の受精能獲得が完全に誘起 されだか否加は不明である。

最近，䉍単な組成からなる等張 $(305 \mathrm{mOsm})$ および 高張 $(380 \mathrm{mOsm}$ ) の完全合成培地空用いて, 射出精 子 $^{80,81)}$ むるいは精巣上体精子 ${ }^{812} 15$ 分閒隔で 2 回洗浄 することにより，受精能獲得の誘起されることが報告さ れ，他の研究者 ${ }^{37,82)}$ によってもこの事実は一部確認され ている.この処理により，精子頭部穴被稪している抗原 性物質の性質が变放るが完全に除去 (受精能獲得) され， 受精が可能になると考元られて就り ${ }^{83,841)}$ ，その免疫学的 な証拠子得られている ${ }^{85)}$ ，しかし，このシステムでは卵 子への精子侵大注遲延し，授精後 $7 \sim 10$ 時間でようやく 始まり ${ }^{80,823}$ ，乙か子顆粒膜細胞赏除去した裸化卵子には 侵入しないのでろ〉おえらくこの処理のみでは精子の受 精能獲得は完全ではなく，処理後に顆粒膜細胞などの排 卵産物と共存することによってそれが完成されるるのと 考えられる.このことは，同様汇処理した精子を卵管に 注入した時，精子は卵子にすぐには侵入することができ ず, さらに長時間雌性生殖器道内にとど充った後に始的 て侵入しうるようになること汭，およで処理直後の精子 からは, arylsulfatase, $\beta-\mathrm{N}$-acetylhexosaminidase 拈よ び hyaluronidase 等の先体醭素の放出が全くみられな ( ${ }^{87)}$ こからる明らかである. 筆者らは，精巣上体精子 に等張および高張の培地を用いて同様の処理を加えた 後, 等張培地で 10 10.5 時間前培養して体外受精客試多 $た^{383}$. その結果，何れの前処理精子においても，授精唩 1 1.25 時間以内に卵子への侵入が始まり，その後の発 生正正常で 48 時間後には 大部分の侵入卵法 $8 \sim 16$ 細胞 期にまで分割した：さらに，裸化率子に抬いても同様の 結果が得られたので ${ }^{88,897}$, 完全合成培地で 10〜10.5 時間 前培養中に精子は受情能獲得（および先体反忘）案完成 したものと考えられる.

授精用の培地としては，酸性㨫溶液に重炭酸塩および ウシ血清 albumin（BSA）家添加した完全合成培地が広
く用いられている 空気の混合领相下で $\mathrm{pH} 7.8$ 宗すが，ウ少ギ卵子の 体外受精俚 7.2 7. $8^{34)}, 7.6 \sim 8.2^{50,60)}$ 西るい注 7.8〜 $7.9^{94)}$ の広い筙围の $\mathrm{pH}$ で可能であり，必ずしも5\% $\mathrm{CO}_{2}$ の添加は必要々しない ${ }^{94)}$.

授精時の精子浱度については，0.6 126 $10^{4}$ 精 子 $/ \mathrm{ml}$ のきわめて広い範囲の浱度が用いられている が61,64,90,91), $5 \times 10^{4}$ 精子 $/ \mathrm{m} l$ 以下の蕽度で注受精率は低 下し ${ }^{95,96)}, 40 \times 10^{4}$ 精子 $/ \mathrm{ml}$ 以上の濃度で安定した高い 受精㳯の得られることが報告されている ${ }^{96)}$.

初期の研究に批いて, 排沺直後の卵子化受精阻害因子 が存在するので，授精前に卵子を数回洗浄することによ り受精率の高くなることが報告されたが58》，ての後の研

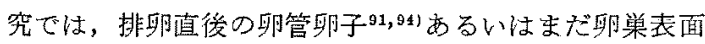
に付着している卵子62,97,99) に括いても高い受精萃が得 ら礼ており，卵子洗浄の効果も確認されていない59,67,9193,95). さらに hyaluronidase 処理により顆粒膜細胞除 去した裸化卵子において毛受精率怟低下しない67,88,89,92， 95). 上卜綫毛性性腺刺激ホルモン（HCG）の注射後 8〜 12時間目の排卵直前の卵胞から採取した卵子においても

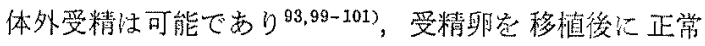
な胎児 ${ }^{932}$ あるい注産子100,101)にまで発育しうる。

受精の確認の方法として，授精後 4 5 時間で卵子穵

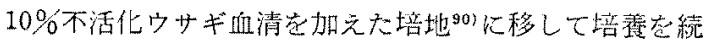
け，20〜25 時間後に 2 4 細胞期にまで分割した眆子を 指摽としている報告が多い、2064,92,94)、笔者らの方法によ ると，精子侵入は授精後短時間内に始宗るので，授精徭 4〜5 時問で卵子を固定·染色して調べると, 此雄両前核, 2 個の極体および侵入精子尾部を明瞅に認好ることがで

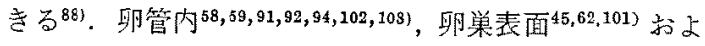

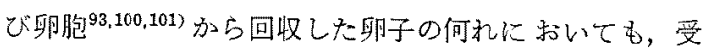
精後 2 8 細胞期に至るまで培㔨它続け, 受容雌に移植す ることにるって正常な産子が得られているが，体外受精 により染色体数異常毁の割合が堌加するという報告も市

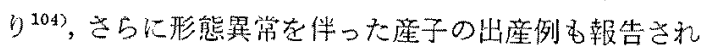
ている102).

$$
\text { ゴールデン・ハムスター(ハムスター })^{17,37,43,55)}
$$

体外で受精能定獲得させた精子な用いて卵子の体外受 精に成功した最初の動物種である105,106).この種では，モ ルモット（後述）と同じように精子の先体反心が光学影 微鏡下で容易化観察されるので，体外受精の研究が急速 に進展し，受精の形態的拉よび生化学的研究の実験モデ ルとして多用されている。しかし，つい最近に至るまで， 精子の受精能獲得と先体反応の完全合成培地内での誘起 は困難で，このために TYRODE 液 ${ }^{106,107)}$ あるいはその修 
正培地 ${ }^{108-110)}$ にムスダ-107.111) やウシ112.119) の卵胞 液, 不活化血清 ${ }^{118-118)}$, 異種動物の盺管液 ${ }^{111,119,120)}$, 副腎

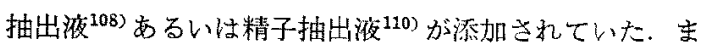
た, 顆粒膜細胞が精子の受精能獲得に効果のあることが 報告されている年,121)，乙の場合，顆粒膜細胞定洗浄子る とその効果が失なっ秃るので，有效成分は乙綥胞間間 質にあるむのと考无られる。筆者らは，修正 KREBSRINGER bicarbonate (KRB) 液 ${ }^{122}$ 空用いて卵子と精巣

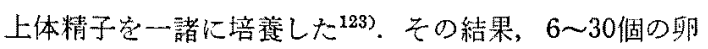
子に一定数の精子志授精すれば，培地の量が少なくなる ほど受精卒は高くなり, $10 \mu l$ 量の培地で $84 〜 88 \%$ 受精 率定得た。同核の実騃条件下で裸化卵子には全く精子僈 入が認められなかったので，顆粒膜細胞間閒質なじの排 畉産物が精子の受精能蒦得と先体反応に有效であったと 推察できる、事実，精子の受精能萑得汪完全合成培地内

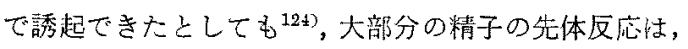
排卯産物の添加後においての不生ずる ${ }^{125)}$.

一方, 八ムスタ一精子の受精能獲得や先体反忘の誘起 に有効な成分の分析が准えでいる。卵胞液や血清に性先 体反応の誘起化有奻な albumin 㥞高分子物貿と精子の遭 㲜性产活発にする(この現象は最初“activated” motility と呼ばれたが126)，徭に“hyperactivation”と改められ

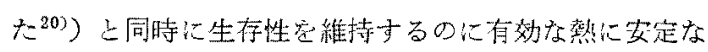

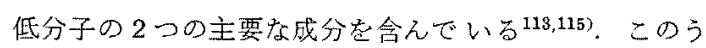
ち高分子物質は albumin と同定され127)，低分子物筫は “精子刺激因子” (sperm-stimulating factor ${ }^{113)}$ ) あるい は“精子運動性維持因子”（sperm motility factor：SMF

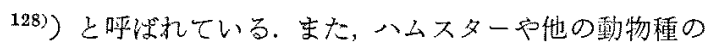
精子の抽出液は，八ムスタ一精子の運動性 ${ }^{129}$ や少体反店

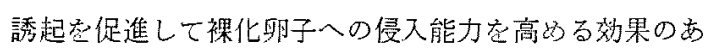
ることが報告され ${ }^{110}, \mathrm{SMF}$ と同じ成分点拿ことが 示された ${ }^{110}$. 巳らに，SMF は精栄上体液 ${ }^{180}$ や副腎抽 出液 ${ }^{131}$ 比多量に合まれていることが明らかにされて

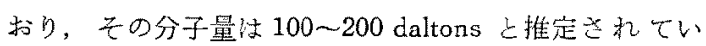
$3^{108,110,131)}$. 最近, 精子運彭の活性化, 先体反心拉よび 畞子への侵入は, SMF と同時に catecholamines および BSA の存在下に拈いての成しとげられることが報告 されている ある taurine および hypotaurine が大量に含ま礼てお $\eta^{135)}$ ，この雨者は八厶スタ一精子の運動性空維持するこ

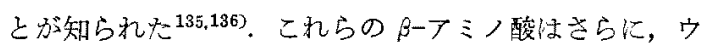
シ卵胞液，ウサギとサルの卵管液拈よび八ムスタ一，乇 ルモット，ヒトの精子にも高浱度に含をれており，物理 化学的な性質は SMF に類似している ${ }^{185)}$. これらのこ しから, albumin $と$ catecholamines 以外に SMF $の$ 代
りとして taurine あるいは hypotaurine 完む完全合成 培地において，八ムスター精子の受精能獲得预よび先体

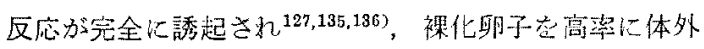
受精させることが可能になった

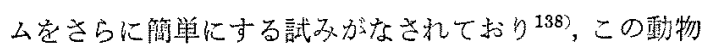
種の受精に加加为西要因分析がより正確にできるように なった。たと光ば，精子と卯子の細胞膜間融合に Ca ${ }^{2+}$

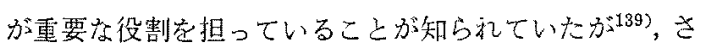
bにこのような完全合成培地を用いて, $\mathrm{Ca}^{2+}$ 蛙子小運 動の活性化，十分な受精能獲得 $\left(\mathrm{Ca}^{2+}\right.$ 欠如下においても ある程度の受精能獲得は可能である), 先体反応と透明帶 通過，さらには前核期卯子の2-細胞期人の分割に必須で

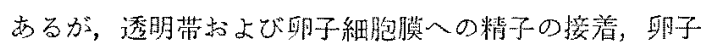
に侵入後の精子棪の拢散と雃雄車前核の形成には必須で

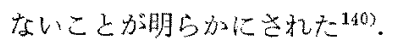

生体液を含掊地等用いた笑験て，幾つかの要因分析 が行われている。镺精能獲得精子による体外受精率は顆

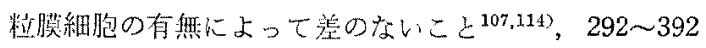

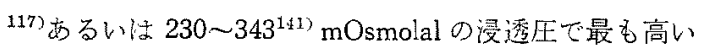
こと, pH6. 8 8.2 の筙国で精子侵入は可能であるが118，

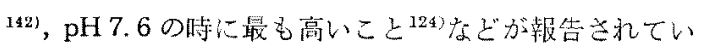
る.受精の場における精子颜度については, $6 \sim 60 \times 10^{6}$ 精

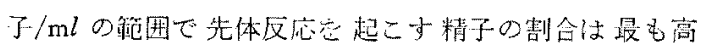

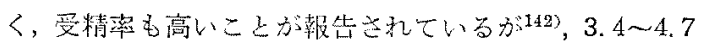

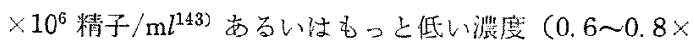
$10^{6}$ 精子 $\left./ \mathrm{ml}\right)^{123}$ でも非常に高い受精街が得られている。

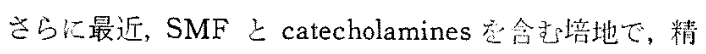

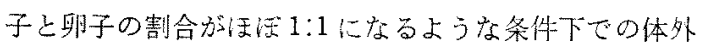
受精の成功例毛報告されてい学 ${ }^{144}$. このように体内条件 と同じような非常に少ない精子数による体外受精驾可能 になれ壮，聊子への精子の侵入栏式なじについてより正 確な分析ができるようになる。这に非常に高い精子浱度 下で大部分の精子に受精能獲得と先体反応定㗭起させう るよらなシスデムの開発も ${ }^{145)}$, 雨者の現象についての生 化学的な研究 ${ }^{146-149)}$ 总進心るのに役立つ。こ礼まで述心゙ てきたほとんどの研焭では，過排眀処理により得た期管 闪卵子々精策上体尾部精子が用いら九ているが，射出精

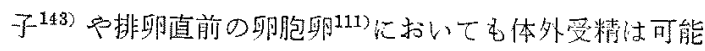

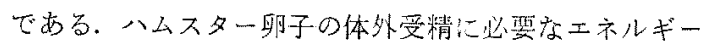
源について調べられたこれまでの饿告106,110,150\}では，受

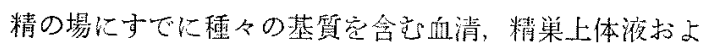
び排應物などが垬存するシスデムが用いられているの

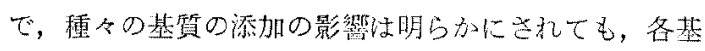
買の厳密な必要性についての分析は困難であった。より 完全な合成培地 ${ }^{1359}$ 空用いて行われた最近の研究による 
と, 八ムスターの洗海精栾上体精子の受精能獲得と先体 反応の誘起には glucose と lactate ダ必要であるが1519, 精子の卵子への侵入については調べられていない。

通常体外没精の寒駼操作性るい人工照明下で行われ るが，とくに䖝光燈の光線に放子䎞長㭙間さらすと，第 2 成熟分裂の阻害されることが報告されて括り，赫な どのフィルター定通した光線下で，できるだけ铻時間内 に卵子老操作寸ることの必要性も指摘されている1522.

授精後卵子への精子侵入が観察ざれる時間は, 受精能 未獲得精子で 2.5 時間11-a), 受精能獾得精子で 10 分以 内113) とされているが, 受精卵の气の後の発生を体外で維

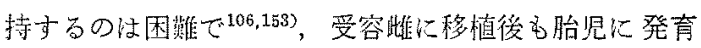

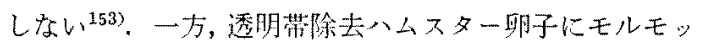
卜 ${ }^{154)}$ や他のけっ荘類155) の精子が侵入しうることが 1972 年に初放て見出されたが，その後，他の多くの動物種の 精子に上当侵入例毛報告され，買種動物精子の受精能 獲得拈よび先体反応の間接的検定のために多用される ようになった（文献 $20 ， 37$ および 156 参照)。さら

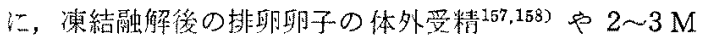
$\left(\mathrm{NH}_{4}\right)_{2} \mathrm{SO}_{4}$ の上うな高濃度の塩溶液保保存後の死滅㽗 子透明带への精子侵入の可能性 ${ }^{159)}$ が報告されている。

マウス $\boldsymbol{ス}^{37,43,55)}$

1968年に子宮精子による体外受精の成功例が初めて得

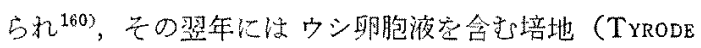
液）空用いて，精栄上体精子に上る受精成立方報告され $た^{161}$. 精渠上体精子は授精後 1 時間で卯子に侵入し始好

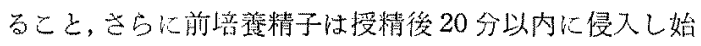
めることから，この動物種においても精子の受精能獲得 の必要性が示㥖された ${ }^{162)} .1971$ 年には完全合成培地(修

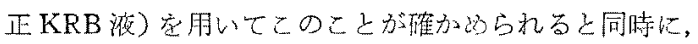
安定した高い受精萃范得ら机ている ${ }^{163,164)}$ 。この動物種 では，体外受精の再現性が非常に高く，受精卵の体外培 養も比較的容易であるので, 以後址界中の異なる研究所 から多様な実駼成績が報告されるようになった。

培地に港加寸る基質などについては，BSA ${ }^{165,166)}$ ，中間

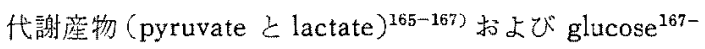

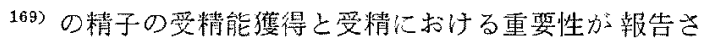
れている．とくに glucose 注，精子の姦精能獲得の最終 段階167) なた结先体反応の誘起 ${ }^{169}$ 和よび卵子透明带通過 167,1699 に必要である。体外受精に最適な培地の浸透压之 $\mathrm{pH}$ 汢, 艺孔ぞれ 308 372 mOsmolal ${ }^{117)}$ そ7.3 7. $7^{118>}$ であるが，pH は精子の受精能萑得よりも卵子への侵入

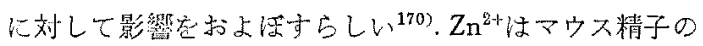
受精能獲得誘起定抑制することが知られている年年1,172). しかし， $\mathrm{Ca}^{2+}$ は精子の運動性維持 ${ }^{173-175)}$, 卵子透明带一
の接着 ${ }^{174.176)}$ および受䊑 ${ }^{173)}$ にとって必須であり，0.34〜 $0.86 \mathrm{mM}$ あるいは $5.13 \sim 8.55 \mathrm{mM}$ よりも $1.71 \mathrm{mM}$ 浱 度の將に有意に高い受精落が得られている ${ }^{177)}$.このよう な条件下で精子の受精能獲得に要する時間は的 1 洔間で あり ${ }^{164)}$ ，精子仙透明带に強く接着して ${ }^{178)}$, 透明鱼に侵 入できると同時に ${ }^{164)}$, 透明带除去後の卯細胞質内にも侵 入できるよらになる ${ }^{1799}$. しかし, 高イオン強度 ${ }^{1809}$, cyclic AMP (0.1 mM) $)^{181)}$ ，および caffeine ${ }^{182)}$ はそれぞれ精子 の受精能獲得叁促進すると報告されている.

精紧上体液㧍よび顆粒膜細胞は何れる受精能獲得空促 進することが示されたが183)，精巣上体液はさしろ受精能 破偯因子 ${ }^{1849}$ を含えでおり ${ }^{173,185,186)}$, 事実精子定洗浄して 精栄上体液を除去しても精子の受精能㤬全く影县を受け ない1877。委た，顆䊉膜細胞も市る条件下ではマウス卵子

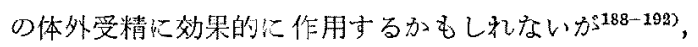
完全合成培地での前培算精子 ${ }^{193}$ あるいは新鮮精巣上体 精子 ${ }^{123)}$ は何れも顆粒膜細胞を有した卵子と同樣に裸化 卵子にも侵入しうることが知られている。

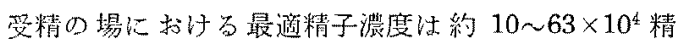
子 $/ \mathrm{m} l$ で ${ }^{194)}$ ，高い受精慗定得るための最低精子数は卵子 1 個当り 100 匹 $^{194)}$ とも 417 匹 $^{196)}$ とも言われている. し 加し，透明带除去卵子では，卵子 1 個当り5 10 匹の受 精能獲得精子が存在していれば受精は成立し，受精卵は 移植後正常な産子にまで発育する ${ }^{196)}$. 透明㴖通過に多数 の精子の存在が必要である理由については不明である. 精子漉度が低くなれば透明带定有した卵子の受精率は低

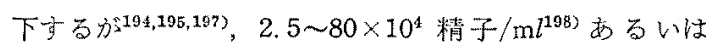
$25 \sim 900 \times 10^{4}$ 精子 $/ \mathrm{ml}^{191}$ の広い筧围で 80\%以上の受精 率が得られている。一方, $200 \times 10^{4}$ 精子 $/ \mathrm{m} l$ 亿対して $400 \times 10^{4}$ 精子 $/ \mathrm{m} l$ 以上むるいは $100 \times 10^{4}$ 精子 $/ \mathrm{ml}$ 以下 の濃度では，受精率江有意に低下し，とくに低精子濃度 洔の受精率には雄による禾統差のあることが報告されて いる ${ }^{1999}$. 精子浱度と多䊑子侵入乞の間に支る程度の相関 のあることが示晙されている200).

マウスの体外受精において采統差のあることは早くか

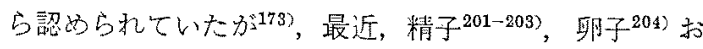
よびその両者205-207)の受精能に明らかな系統差のある

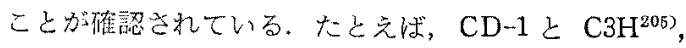
$\mathrm{TO}^{2023}$ および $\mathrm{CBA}$ 系統2063 の精子は買なる系統のマウ 不卵子によく侵入しうるが, $\mathrm{C} 57 \mathrm{BL}^{202,205-207)}$ あるいは $\mathrm{KE}$ 和よじ $\mathrm{KP}^{206)}$ の精子は，同系統の久ならず他の系 統の卵子との受精率も低い，同系統の精子と莭子を用い

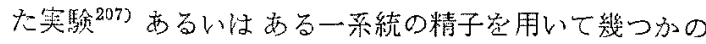
異なる系統の卵子に授精した実験 204 では，精子侵入の 時期と侵入後の卵子の発生速度に明らかな系統差が㕕ら 
れる.ある系統の精子の低受精能は適当な培地穵選択す ることによって改善されうる ${ }^{205)}$.

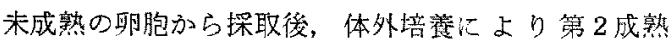
分裂中期に達した卵子の体外受精も可能であるが173,188.

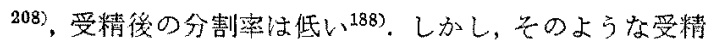

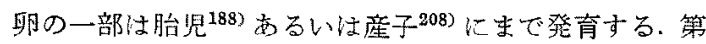
1 成㷫分裂の如何なる時期の未成熟卵子に打いても透明 帯への精子侵入住可能であるが，卵細胞質内での精子頭 部の变形は中期以降に達した慨飞において初好て正常に

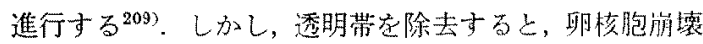

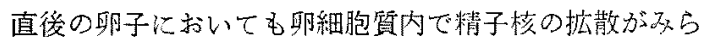

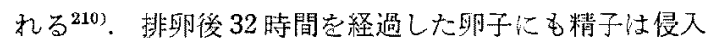
しうるが，12〜14時間以上経過すると，ほとえどの侵入

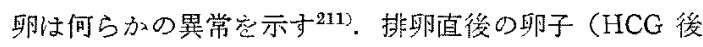

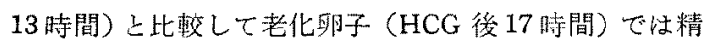
子侵入と前核形成为促進される ${ }^{212)}$ ，また，勤物自体の老 令化に伴って卵子の体外受精率が低下するとも213)，しな

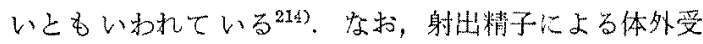
精215) 户凍䋹融解後の排卵卵子の体外受精158,216) 无報告 されている。

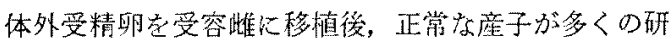
究所で得られている189,191,208,217,218). しかし一方では，体 外受精により染色体数珙常卵の割合の増加することが報 告されている 性腺刺激ホルモン（PMSG）の投与量の増加に伴って, 多培体の割合が增加し，これはほとえど多精子罗精心起

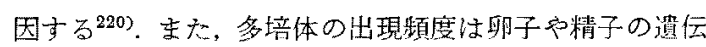

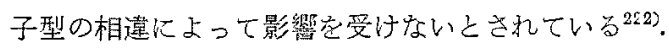

$$
\text { チャイニーズ・ハムスター }{ }^{37,43)}
$$

1969 年心最初の成功例が報告されたが223)，以後傕認 の報告はない、ゴールデン・ハムスターの卵丘塊（即子

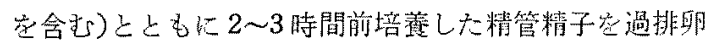
誘起後の卵管卵子あるいは成熟卵胞から採取した卵子に 授精した．培地としては，TYRODE 液または1\%BSA 加

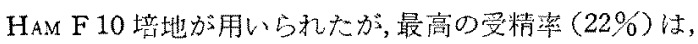
HAM F $10+$ BSA て前培䓹した精子と卵管畉子との組合 わせで得ら沉た。第 2 極体上此雄闭前核の存在および囲

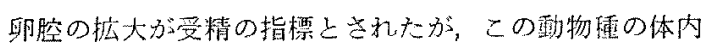
受精に志いても少数例観察されているように ${ }^{224}$, 精子尾 部が䀦細胞質内に取り込まれた即子は見出されていな い，掦藏された写真加らも受精の成立は明らか上思的九 るが，精子の受精能獲得に必要な条件または精子侵入の 時期などについてさらに検討艺姴する。

ネコ ${ }^{37,43)}$

子宮精子（射出精子家外科的に注入後に回収）による
体外受精の成功例が 1970 年に初的て報告された ${ }^{225)}$ 。す なわち，HCG 注射後 30 㭙間の排卵卵子に授精し，26〜 42 時間後に分割卵度受精の指標とした結柴, $0.5 \sim 1$ 時間

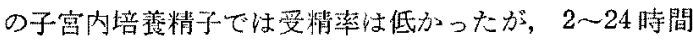

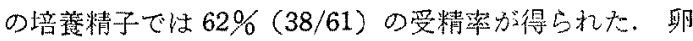

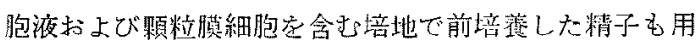
いられたが，分割卵は得られなかっだ225．1977年に， 完全合成培地である修正マウス受精卵用培地（BWW 液 $)^{226)}$ または修正 HAM F 10 培地空用いて体外受精の成

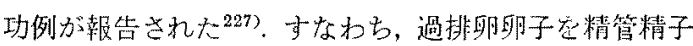

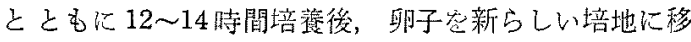
し，その後 12 㭙間の間河で卵子の分割が調べられた。 そ の結果，78～81\%の高い受精露分得られ，雨者の培地間 で受精率に㸝は認められなかった。筆者ら（未発表）は 最近，修正 KRB 淮 ${ }^{122}$ 定用いて，過排卵卵子空精管一精

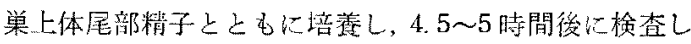
た結果，7個のうち6個の卵子において侵入精子尾部を 伴った明白な受精の初期像（膨化精子頙部上第 2 成熟分

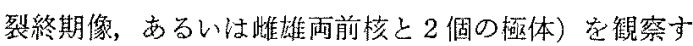
ることができた。これらのことから，ネコ精子の受精能 獲得は非常に短歭間内にしか子容易儿誘起されると考充 られるが，その必姴条件などについてさらに追試による 検討が必要でする。

\section{スナネスミミ゙7)}

50\%のウシ卵胞液定食它 TYRODE 液 $(20 \sim 100 \mu l)$ \%

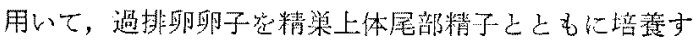
ることによって体外受精の成立することが脽一報告方れ ている ${ }^{228)}$.この条件下において一部の卯子では授精後 3 時間で精于の透明带通過と前核形成か認的与れ，4〜6時 間後には受精案は 54\%に達した。卵胞液定添加しない TYRODE 液においても，授精後 4 6 時間で 40\%の受精染 加得られ，精子の受精能萑得誘起に性必らずしも卵胞液 は必要でないとされている。しかし，この報告で示され

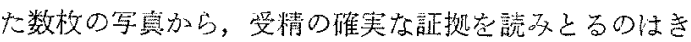

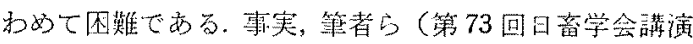
要旨, p. 77 参照) 江，上部の条件以外儿も種命の条件下

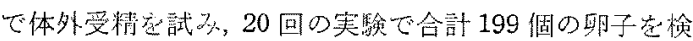
查したが，精子侵入の証拠は全く見出されなかった，透 明带除去卵子の一部で受精初期の西䒠在証拠が観察され たが，現时点ではこの秒物種の体外受精はきかるて因奞

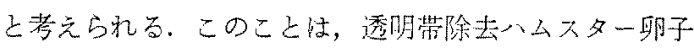
に対してもスナネズミ精子の侵入はほとえど起こらない ことからも推祭できる

モルモットア3,43,55

精舁上体精子による白然排卵㓪子の傕実な体外受精 


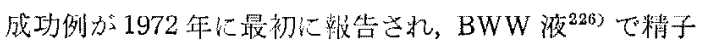

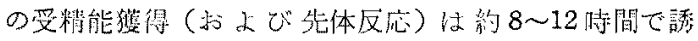

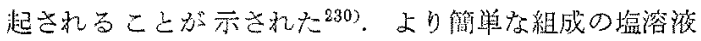

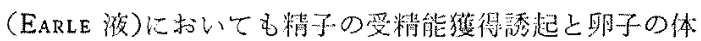

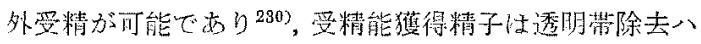
ムスター卵子にも侵入しうることが報告された ${ }^{154)}$.つい

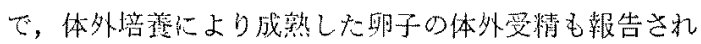

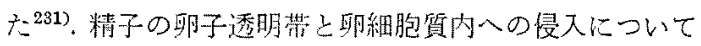
雷顕レベルでの詳細な観察もなされている232).

精子の先体反応誘起に対与告 $\mathrm{Ca}^{2+}$ の重姴性が，体外

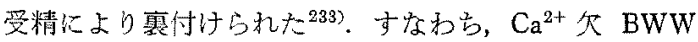

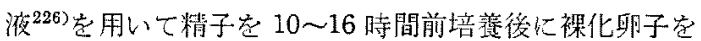

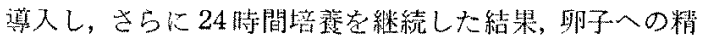
子侵入は全く認的られなかった。しかし，卵子導入時に $2 \mathrm{mM}-\mathrm{CaCl}_{2}$ 点添加卞る乙, 10 分以队心精子の先体反応 が誘起され，2時問以内に全ての卵子に精子侵入が詔め

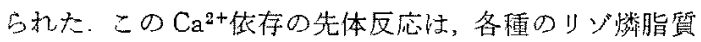

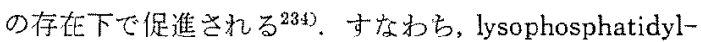
choline $(85 \mu \mathrm{g} / \mathrm{ml})$, -ethanolamine $(210 \mu \mathrm{g} / \mathrm{ml})$ ま は-inositol $(140 \mu \mathrm{g} / \mathrm{m} l)$ 总含む $\mathrm{Ca}^{2+}$ 欠培地（修正

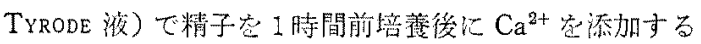

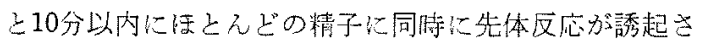

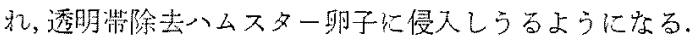

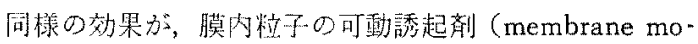

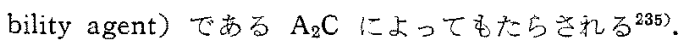
一方，先体反応を起こした精子だけ空分離する方法が開 登され ${ }^{236)}$ ，叹な精子は少なく已す2時閒は透明带

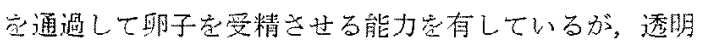

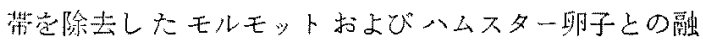
合能打 8 時間後まで保有されることが的らかにされ

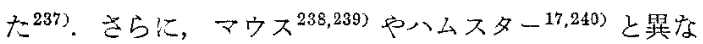

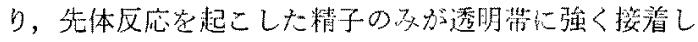
て，卿子内に侵入しうることが観察されている゙20,236).

一方，精子の受精能萑得と先体反応は， $\mathrm{NaCl}, \mathrm{CaCl}_{2}$, $\mathrm{NaHCO}_{3}$ および lactate culture medium: MCM) 内で 3 㭙間以内心誘起される

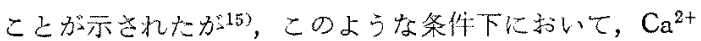
欠如下の精子の嗫精能獲得誘起は $\mathrm{pH}$ に左右さ礼, 7.8以 上の㭙においての正可能であること，また先体反応は

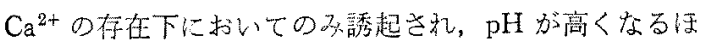
己゙促進されることが献告さ机ている241. $\mathrm{pH} 7.8$ 以下で $\mathrm{Ca}^{2+}$ 留源加の埸台には, 精子の受精能獲得は, モルモッ

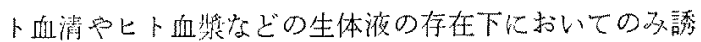

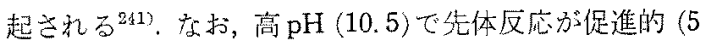
分以内）に誘起された精子は容易に卵子に侵入しうるの
で，生理学约红正常と梦えられている241)、MCM 定用い

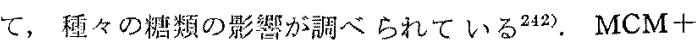
glucose では,とくに glucose の泳膺が $1 \mathrm{mg} / \mathrm{ml}$ 以上に なるる，精子の先体反応の䜍起は4㭙間以上に孙たって 注活完全に抑制已れ，fructose p mannose 手同様の抑 制約热有するが，L-fucose，D-galactose, sucrose お よび L-glucoseのような非代謝性の糖には抑制効果がな い.このことは、 MCM よりも MCM+glucose で 3 時

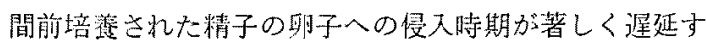

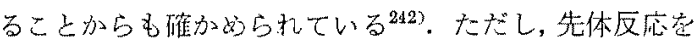
起こした精子が卵子に侵入するためには，培地に $\mathrm{K}^{+}$の 存在することが必要であり，その最適鼬度は $1 \sim 2 \mathrm{mM}$ の間であることが報告されている243).

モルモットでは過排卯誘起は困難であるが，精子が

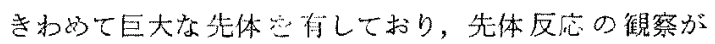
容易であることから ${ }^{2201}$ ，先体反応飞関する研究加活発

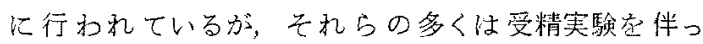
ていない。たと文ば, 界面活性剂244, ionophore A $23187^{245,246)}$, methoxyverapamil ${ }^{247)}$ 占よび cyclic GMP ${ }^{248>}$

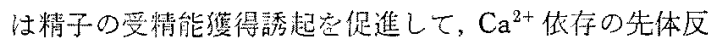

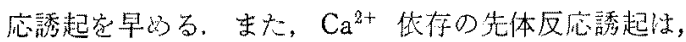
$\mathrm{Mg}^{2+}$ によって競合的に阻害されることなどが報告され

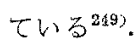

\section{ラット (37, $43,63,55,250)^{2}$}

1968年に透明荤定除去した卵子人の精子侵入例が得ら れたが2519，透明带密有した蔇子については，子宫精子に よる体外受䞍の成功例が 1973年心初好て報告された 253)。乙の翌年には完全合成培地（修正 KRB夜）を用い

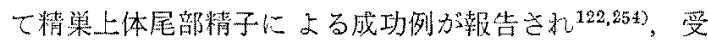
精卵は移㥀後に胎児および産子にまで発育しうることが 知られた つの原著竍告がなさ礼た米国ウースター研究所の M.C. CHANG 博土の研究室で行われたすのであり，他の研究室

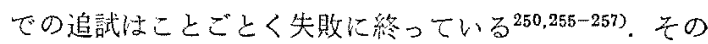
理由については不明であるが，この㗢物種では，温度， 杀釈または他の未知要因などの環境变化に対して精子の 抵抗性が弱いので258，研究者の技街的な熟練度が大きな 原因の1つになっている可能性加方る259,260).

ラットの体外受精において最む特徽的なことは，精子

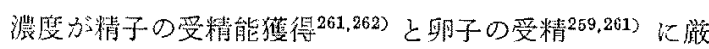

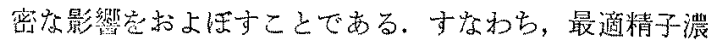

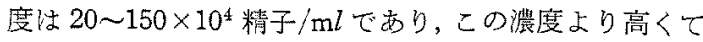

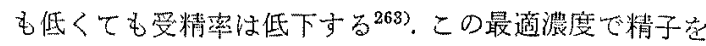
5〜7時間前培率すれば，精子性授精後 30 分以内に即子

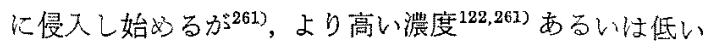


搌度 ${ }^{262}$ で前培着した精子の受精能は極端に昏下する、し

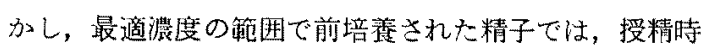
の濃度を極端に低くしても $\left(1.0 \sim 1.6 \times 10^{4}\right.$ 精子 $\left./ \mathrm{ml}\right)$, 体外受情は可能である ${ }^{262)}$ 。一方，体外受精が不可能な商 い濃度で前培坫された精子を倠の子宮内に注入すると 5 5. 5 時間後に体内での受精は成立する264).さらに, 高 $\mathrm{K} / \mathrm{Na}$ 比方るいは cyclic AMP の誘尊体を含む条件下 で仗，比較的高い精子䟴度 $\left(300 \sim 600 \times 10^{4}\right.$ 䞍子 $\left./ \mathrm{ml}\right) に$ おいても，前培靠により精子の受精能獲得が誘起され $b^{254)}$

培地の条件について幾つかの要因分析が行われてい る，血清 albunin は必須成分であり，4 $4^{265)}$ たは 10 $\mathrm{mg} / \mathrm{m} l^{266)}$ の結晶 BSA の存在下で高い受精梁加得られ るが, ovalbumin と他の一連の蛋白質悖受精に対してほ こえど效果が諰められない266. $\mathrm{Ca}^{2+}$ 欠培地では受精は

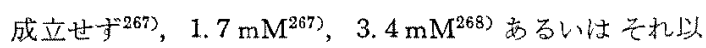

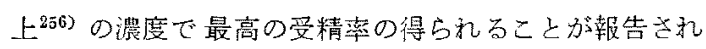
ている、培瘎中の気相について，空気+5\% $\mathrm{CO}_{2}$ の条件 下では堷地（修正 KRB 液 ${ }^{122)}$ の $\mathrm{pH}$ 《 7.0〜7.1 k保 たれ受精率も高いが，空気のみの気相下では，8１0時 間の培養俊心培地の $\mathrm{pH}$ が7.6〜7.8 已富くなり, 支のた

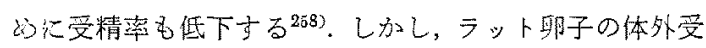
精は 7.4〜8.0の範囲の pHで可能であり，pH7.8で最

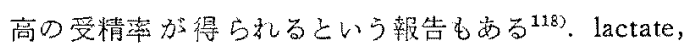
pyruvate および glucose は全て基質として裸化畉子の

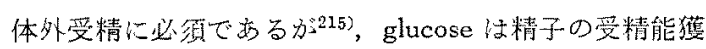
得よりるむしる卵子への侵入時に必慗であり，mannose は glucose に代用できるが，fructoseき galactose は代 用できない2699.前述のよう《，マウス ${ }^{180) や ウ サ キ ゙ 80) て ゙ ~}$ は高イオン強度培地での受精能獲得の促進現象が報告さ れているが，ラットでは対照 (309 mOsmolal) に比較し て 357 397 mOsmolal の培地隹おいてわず加に要精能 獲得の促進が認められるが，より高いイオン強度 (477 mOsmolal) で注，注とえと瞬間的に精子の運動性加失 なりれる ${ }^{270)}$.

HCG 注射後 6 時間までの卵胞から埰取した卵子に比 ベて 6 10 時間の眀子（第 1 成熱分裂中期以降）の受精

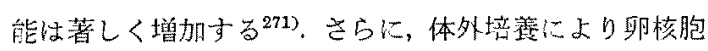
期から第 2 成熟分裂中期安で成熟した眼子の体外受精も 可能であり，受精率は初期 $(18 \sim 22 \%)^{271)}$ よりる後们行 われた研究 $(40 \sim 97 \%)^{272,273)}$ で著しく高くなっている が，精子の昴子の侵入時期が暒延し，正常な受精の過

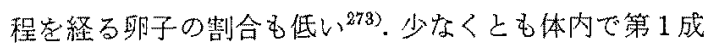
熟分裂中期に達した後に体外で第 2 成熟分裂中期まで成 熟させた即子では，受精案おるび正常な発生㱏続ける卵

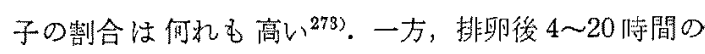
卵子では精子侵入染に差珄認められないが，正常な受精

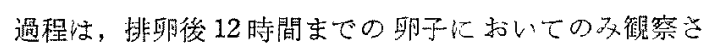

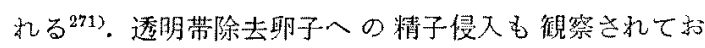
り，この場合もやはり精子の受精能爑得誘起が必要で

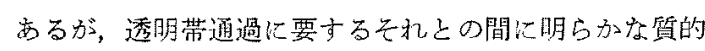
な相量のあることが示唆されている274)、濑結融解後の体

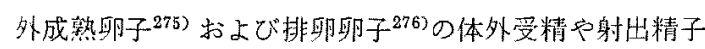
による体外受精216) の可能性も報告されている.

その他の要因心ついて注，白然排卵即子よりも過排卵 卵子の方が体外受精が容易であるこ充，正常な受精 总得るための培地の量は，100〜400 $\mu l$ が適しているこ $と^{122,2583}$, 少なくとも $\mathrm{CD}$ と Long-Evans の両系緢の ラット間258) および Wistar 系のラット277 においてす体

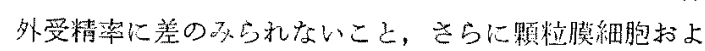

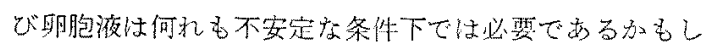
れないが265》。り安宗在条件下では受精にとって不可久 でないこと258〉などが频告されている。

体外蓡精卵に由来する産子に小眼症が高率に出現した 例が報告さ秃ているが，体外受精との因果闂係は不明て

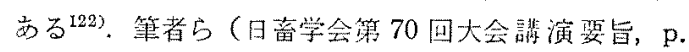
39,1979 参照) は, 同様の移植实駰で，産子に少なくと 毛外観における北態学的買常住何ら認めていない。

リスザル ${ }^{37,278)}$

20\%の子ゥシ血清它含さ TC 199 淮 $(0.5 \sim 1.0 \mathrm{ml})$ で

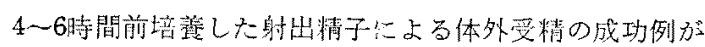

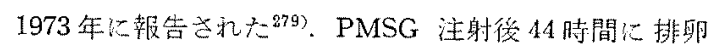
直前の卵胞から畞子它採取し，上記の堷地江浮遊させ，

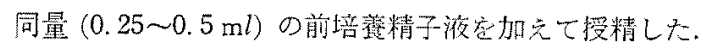
授精㷋 72 㭙閒に至るまで合計 22 個の即子立检㚗した結 果，11 個が受精の初期徵候（国卵腔内への精子侵入，第

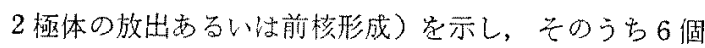

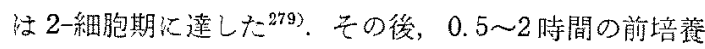
精子と卵胞剌激ホルモン (FSH)-HCG 处理後 4 12 時

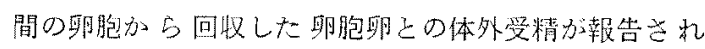

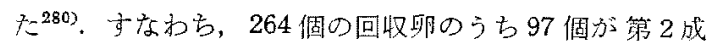

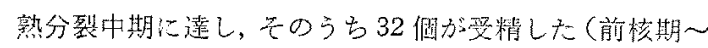

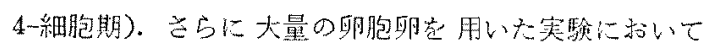
本，任洁同㥞の体外成熟案 $(233 / 608=38 \%)$ と体外受精 率 $(78 / 233=33 \%)$ 方得られているが，前核期〜4-細胞 期の受精卵を受容倠に移植しても旗床させることはでき なかった 尔，受精の時間的経過については，授精後 6 時 間までに精子僈入と卵維胞質内で膨化精子頭部少よび侵 入精子尾部が，また10時間までに前核形成がそれぞれ徼 察され，さらに24〜30時間で 76.6\%の受精卵において 
第 1 分㓶中期像が観察されるこ報告されている2821。こ

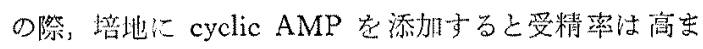
る282)。また受精卵の染任体分析の結果，11.7\%の卵子名

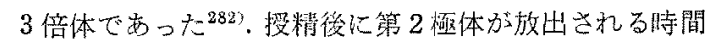
加ら，精子の受精能獲得心要方年㭙間は最子早くて2 時 間である己推定されている283). 上記の報告のうち2つに

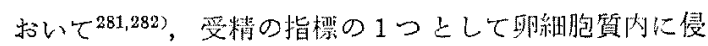
大精子尾部定確認しているが，它の明白な証拠（写真） 定示した解告性見当らない，精子の受精能獲得化要寸る 時間についてむ，直接的な实驗による証明が必要と思和 れる。

\section{イ $又^{87,38,43)}$}

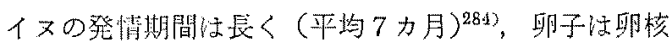
胞の段階で排卵されるが285)，排卵の予知は困難である ${ }^{236)}$. そこで，卵胞から採取した卵核胞期の卵子空用いて

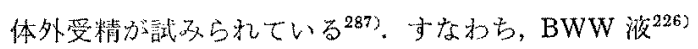
$(0.5 \mathrm{ml})$ に浮遊させた洗沵射出精子 $\left(100 \sim 500 \times 10^{6}\right.$ 精 子 $/ \mathrm{ml}$ ) 究採取直後あるい忙 24 72 時間培盖 (TC 199+ $20 \%$ ウシ胎坚血清) 後の卵子に授精した結果，7洔間後 亿精子の先体反応と透明带への侵入が観察された。授精 後 11〜24 時間で卵子空固定・染色して検查した結果, 何 れの成熟段階にある卵子においても精子侵入が認めら れ，一部の卵子では精子頭部の膨化が観察された ${ }^{2872}$ 。 の後，完全合成培地内での精子の受精能獾得战よび先体 反応の誘起の同能性について調べられ，BWW 液 ${ }^{266}$ 苍 さらに修正したイ又精子の受精能獲得用培地（canine capacitation medium) が開発された

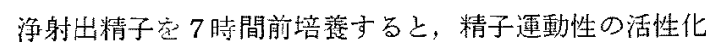
（ハムスターの項参照）上先体反応の撛起が観察された。 このような精子を裸化培荃卵子に授精した結果，1〜2 時 間後に $71 \%$ の卵子に精子侵入が認められた，この培地で は，精子の先体反応の誘起に対して Ca ${ }^{2+}$, BSA および glucose の存在は必須であり，逆に $\mathrm{Mg}^{2+}$ 沈わずかに一 水を遲延させる +glucose および BSA の培地でも，精子の先体反応誘 起と卯子人の侵入は可能であるが，卵子細胞膜との融合 は起こらず， $\mathrm{K}^{+}$の必要性が指摘さ机ている ${ }^{2881}$.

\section{ディーア・マウス}

最近, 2 程類のア゙ィーア・マウス (Peromyscus maniculatus ${ }^{229,289)}$ 小よび P. polionotus $\left.{ }^{289}\right)$ において体外受精 の成功例多報告されている. 修正 KRB液 $(0.4 \mathrm{~m} l)^{122)}$ 责 用いて, P. maniculatus の精紧上体尾部精子を 9 12 時間前培蒦後纪過排卵卵子に授精した結果，19〜140 (4.5\%)よりむ254 454(38.9\%) ×106 精子 $/ \mathrm{ml}$ の精子濃 度において受精率は高かった ${ }^{229)}$. また，P.maniculatus
とP.polionotus の両種に扎いて,それぞれ同種内あるい は两種間の配偶子に上る体外受精が試みられている2899. この報告では, 修正 KRB 液 $(0.2 \mathrm{ml})^{163)}$ で 2 時間前培 䔲した精巣上体尾部精子が用いられているが，何れの配 偶子の組合るせに沶いても，授精後20〜23時間で高い受 精率 (79〜93\%) 淂られている.しかし, 精子の受精 能獲得に要する時間について直接的な检討はなされてい ない。

\section{J.I. 家畜の体外受精}

\section{ヒツジ38,40,43,56)}

大型家音のら台で最も早期 (1959 年)に獒礎的な実験

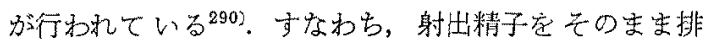
卵卵子に授精してむ受精卵住得られなかったが，交配後 12〜24時間の倠ヒッジの子宮頸あるいは子宮角から回収 した精子老用いると，授精後 5 時間以内に 78 個中 4 個の 卵子に拈いて第2 極体の放出あるいは 2 個の前核形成が 認好られた。 その後, 子宫角あるいは卵管内で $2 \sim 7$ 時間 培養した精子を用いて，23 個中 4 個の卵子において精子 侵入が認文られている2911. 最近, それぞれ蛋白質無添 加, 3\% BSA 添加または 20\%子ヒッジ血清添加の2 種 類の完全合成培地老用いて，体外受精の成功例洂報告さ れている292)。すなわち，射出精子を上記の培地 $(1 \mathrm{ml})$ で

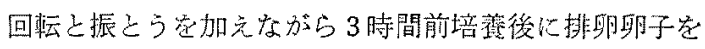
添加し，さらに3時間培養を継続した（95\%空気＋5\% $\mathrm{CO}_{2}$ )，その後，卵子を同じ培地に移してさらに 48 時間

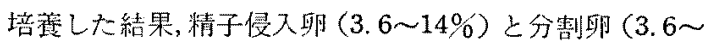
8\%)の割合は何机る異宗る培地間で差が認奶られなかっ た. また，ionophore A 23187 処理により先体反応を誘 起させたヒツジ精子は，透明帶除去後の卵子細胞膜と融 合できるが，透明带空通過する能力のないことが報告さ れている293).

\section{ブタ ${ }^{38,40,43,55,56)}$}

畉胞畉と排卵卵子を用いた基璴的な実験が1970年に報 告されている29:1)。すなわち, 卵胞卵については, 卵胞液 で培䓹後に子宫精子と卵管液中で授精した時（約 19\%）， また排卵卵子については，卵管液を受精用培地として，

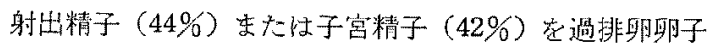
に授精した時にそれぞれ最高の受精率が得られた。その 後も同一研究者による同様な実験で受精の成立が報告さ れたが295)，受精の指標之された第 2 極体の放出之前核形 成は何れも立の事寒が明白汇注示されていない，事实， ほ医同様の方法密用いて行われた他の実験では, 卵子一 の精子侵入は確認されていない2963. 一方, 摘出された子 宫および卵管内で前培養された射出精子による体外培養 
卵胞率への侵入の可能性が示唆されたが297，後に受精初 期の明白京証拠が写真によって示された 2983. 修正 KRB 液 ${ }^{122)}$ で前培荃精子は卵子一の侵入が困奞であったの で, 摘出された雌プタの雌性生殖器道内での前培萑はブ タ精子の受精能爑得誘起に効果のあることが示唆され た ${ }^{298)}$.このことは，このような精子と透明带除去八ムス

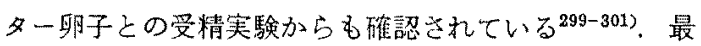
近, ionophore A 23187 で前処理された射出精子および 精巣上体尾部精子による体外受精の成功例も莭告されて いる（豊田ら，日畜学会第 72 回大会講演婯旨，p. 144 , 1981 および同 73 回大会請演要旨, p. 81, 1982 定参照.) また，Na-pyruvate，Ca-lactate，glucose および子ウシ

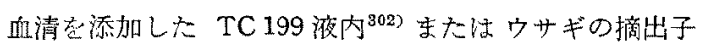
宮内 ${ }^{303)}$ で前培養された射出精子に上る透明帯除去後の 八ムスター ${ }^{302,303)}$ およびブダ3021 の即子への侵入例名報 告されているが，これの精子が透明带学有したブタ即子 に侵入しうるか不加調べられていない。

\section{ウシ $98,40,48,55,56)$}

初期の実験で，体外成熟卵胞卵304.305) または排卵直前

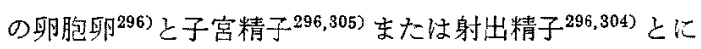
よる体外受精が試父られたが，何れ妥精の確証は得ら

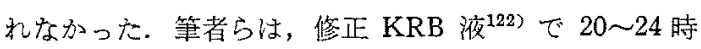
間培䓹した卵胞卵乙種々の処理を加光た射出精子を用 いて体外受精を試及，精子侵入の明確交証拠を得た ${ }^{306}$. すな⿰ち，培地内で 12〜14時間, 発情此倠ウシから摘出し た子管または卵管内で 3〜4時間, および発情䧳ウサギの

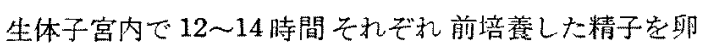
子に授精し，18～21 時間後に検䍒した結果，それぞれ 0 ,

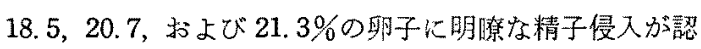
められた，精子侵入の正確な時期については調べられて いないが，同種または異種動物の比性生殖器道内環境は ウシ精子の受精能獲得誘起に效果のあることが示咍され た. その後, PMSG と prostaglandin $\mathrm{F}_{2} \alpha(\mathrm{PG})$ を用い て過排卵誘起を行い，外科的に採取した卵胞卯または卵 管卵子に高イオン強度の培地 ${ }^{80}$ で好理した精子定授精 し，56\%(14/25) の卵子において前核形成女たは2ー一 4-細胞期への分割乱よび表層粒の消失が観祭されてお り，電顥レペルでその正常性が確かめられだ07)。この高 イオン強度処理精子は体外培苌後の成熟莭子にも侵入可 能である ${ }^{308)}$. 同じ方法它用いて行われたさらに大規模な 実験から，受精率仗PG 処理後卵子採取までの時間によ つて影響定受け， $67 \sim 76$ 時間の卵子では比較的高い受精 率少得られるが, 若いホルスタイン㮔雄牛 $(5 / 26=19 \%)$ よりまジャージー種雄牛 $(14 / 28=50 \%)$ 加ら得た精子 において受精率の高いことが示さ机た ${ }^{309}$.さらに, 凍結
融解精子による体外受精も可能である ${ }^{310}$ ：ごく最近， 4-細胞期の体外受精卵走受容此に移植して正常な産子か 得られた ${ }^{310)}$.

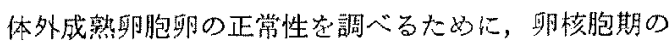

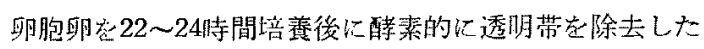
成熟卵乙培地（ $\mathrm{NaHCO}_{3}, \mathrm{Na}$-pyruvate，Ca-lactate,

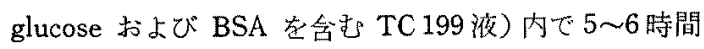
前培荃した精巣上体尾部精子との体外受精が陚子られて いる311)，授精後 12〜14 時間で検查した結果，575 個の 供試卵のう方 510 個 (88.7\%) に精子侵入が認められ， 261 個 (45.4\%) は正常な雌雄両前核堂有していた。す なわb，体外成䰻卵の約半数において，卵細胞資自体の 成熟も正常であることが示惨されだ11.

ウシ精子の受精能獲得の指標の1つとして, 透明带 除去八厶スター卵子への侵入例が威つか報告されてい

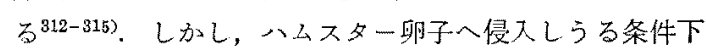
で，ウシ溉人の侵入る可能であるか否かについて調べ られた報告は少ない314,315)、箱者ら(末発表)は，ウシの 卵子に侵入できるように処理した精子2987究用いて，透明 带除去一ムスター卵子に授精したが，精子侵入例は得ら れなかった。

\section{ヤギ}

筆者らは，ヤギ射出精子を未経産䧳ブタの摘出子宮お よび卿管内で 5 5.5 時間前培養後に透明带除去心ムス ター卵子に授精した ${ }^{316)}$. その結果，授精後 2〜5 時間で， それぞれ 52〜63\%少よび 38〜76\%の卯子に精子侵入が

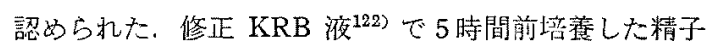
では卵子への侵入はほとえど認められなかったので，異 種勤物の比性生殖器道内で精子に何らかの生理的变化が 誘起されたと考えられるが，このような精子は透明带を 有した卵子には侵入できず，透明帯丟除去した卵子にの 侵入することが観察されている ${ }^{317)}$.

\section{III. ヒトの体外受精 ${ }^{37,39,43,551}$}

体外罣精の確实な成功例が1969年に初的て報告されて 以来 ${ }^{318)}$ ，多くの実験成績が報告されるようになったが， 畉胞から探取した卵胞畉と射出精子が共通して用いられ

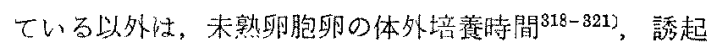

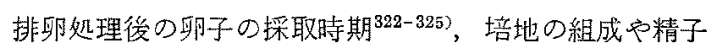
の前処理法318,320.322,324,326.327) は研究者によって艺れぞれ 異なっており，精子の受精能獲得に要する㭙間および精 子侵入時期について詳しく調べられた報告は少ない。最

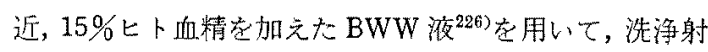
出精子共体外成熟卵子に授精し，2.5 時間以内に精子侵 人の始まることが観察された ${ }^{327}$ ，さらに，5 mg BSA/ 
$\mathrm{ml}$ 苦含む修正 TYRODE 液で 1.5 洔間前培䇉した精子は， 排卵㨁前の卵子に授精後 3 㭙閻以内に侵入し始めること が篗察され，約 3 4 時間で精子の受精能獲得の諲起され ることが示㖟された ${ }^{325)}$ 。篚者らも，修正 KRB液 ${ }^{122)}$

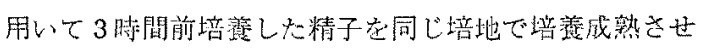
た卵子に授精し，10洔䦩後に 39.6\% (19/48) の受精率 在得でいるので328)，完全合成培地内で比較的容易に精子 の受精能獲得が誘起己れるものと思われる.

母体へ移植された体外受精莭に由来与る正常な子供の

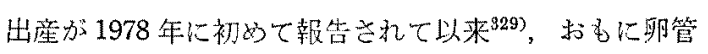
障害儿上る不妊㷌人の治瘈手段として体外受精技術の応 用の重要性が注目己れるるうになった。現在，世界中で 体外受精卵の移㥀による娃娠例あるい法出産例多多数報 告されているが330-336)，一方ではそのような治燎の青当 性についても多くの諭呯がなるれている(たとえば，文 献 337 339 荧参照).

ヒトでは男性不妊に関する臨床上の視点から, 精子の 受精能が子知できれ代常に有用となるが，体外受精を 応用してそれ間管的に判定しるうとする試多がなれ ている，たと文壮，透明带除去心ムスター卵子に受精能 篗得七ト精子の侵入しうることが1976 年に初めて見出

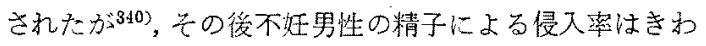
めて低いことが報告されている

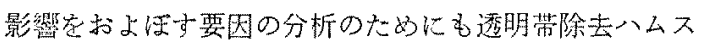

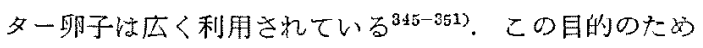
に，凍結融解後の透明带除去八ムスター卵子も使用でき る352).な格，マウスやラットの唀明带除去畉子にはヒト 精子注侵入することができない吕3,354)。受精能獲得ヒト 精子は, $3 \mathrm{M}\left(\mathrm{NH}_{4}\right)_{2} \mathrm{SO}_{4}+0.1 \%$ dextran たは $1.5 \mathrm{M}$ $\mathrm{MgCl}_{2}+0.1 \%$ PVP のような非常に高濒度の塩溶液に 保存されたヒト卵子 ${ }^{159)}$ あるいは死後数日を経過した死

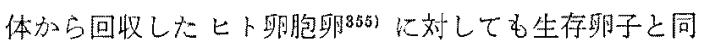
しように侵入しうることも報告饥ている。

\section{おわりに}

以上, 各諭的に体外受精の現沉について述べてきたが， ヒト以外の哺乳動物では，長年にわたる基礎研究の積重 ねがある飞るかか如らず，体外受精莭の移植により産子 の得られている動物はわずかにウサギ，マウス，ラット およびウシの4種に限られ，しかもその実験例数恃きわ めて少ない，一方，ヒ卜に拈いては，体外受精の技術が 臨床上最も有効に利用できるので, 基礎研究の段階を飛 越して，一気愎床灾用（体外受精䀦の移植）に向加っ て研究が進展しているようである.しかし，その可否に ついての論議は本稿の目的ではない。家畜に拈いても体
外受精の応用がもたら方効果は大きい，たと光ば，末成

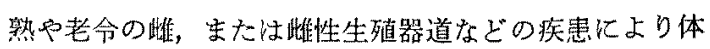
内での受精汃困雉になった優良雌からの卵子を有効に利 用することができる、さらに，(未)受精卵の谏結保存， 精子あるい性受精卵の斟雄分别, 種々の遗伝子工学的手 法などの諸技術と組合わせることによって，家畜の育種 的改良性著しく促進されうる。しかし残念ながら，实娩 用小晴乳動物に比較して，いわゆる狭義の家畜における 体外受精の研究はようやく緒についたばかりといってる 過言ではない，本稿多，家畜繁殖技県の准歩のために何 らかの絜材定提供できれ忧萃いである。

\section{文献}

1) Austin, C. R., Aust. J. Sci. Res. Ser. B, 4: 581586. 1951.

2) Chang, M. C., Nature, 168: 697-698. 1951.

3) Austin, C. R. and M. W. H. Brshop, Proc. R. Soc. Lond. Ser. B, 149: 241-248. 1958.

4) Pikó, L. and A. Tyler, Proc. Vth Int. Congr. Anim. Reprod. A. I., Trento, 2: 372-377. 1964.

5) Thibault, C., L. Dauzier and S. Winterberger, C. R. Soc. Biol., Paris, 148: 789-790. 1954.

6) Dauzier, L., C. Thibault and S. Winterberger, C. R. Acad. Sci., Paris, 238: 844-845. 1954.

7) Chang, M. C., Nature, 184: 466-467. 1959.

8) Austin, C. R., Int. J. Fertil., 12: 25-31. 1967.

9) Austin, C. R., Ultrastructure of Fertilization. Holt, Rinehart and Winston. New York. 1968.

10) Austin, C. R., in Advances in Bioscience Vol. 4. (Raspe, G., ed.) 5-11. Pergamon Press. Vieweg. 1970.

11) Bedford, J. M., Biol. Reprod., Suppl., 2: 128158. 1970

12) Srivastava, P. N. and W. L. Williams, in Control of Human Fertility. 73-83. John Wiley and Sons, Inc., New York. 1970.

13) Williams, W. L., in Biology of Mammalian Fertilization and Implantation. (Moghissi, K. S. and E.S. E. HAFE $Z$, eds.) 19-53. Charles C. Thomas. Springfield, Illinois. 1972.

14) McRorie, R. A. and W. L. Williams, Ann. Rev. Biochem., 43: 777-803. 1974.

15) Barros, C., in Physiology and Genetics of Reproduction, Part B. (Coutinho, E. M. and F. Fuchs, eds) 3-24. Plenum Press. New York. 1974.

16) Chang, M. C. and R. H. F. Hunter, in Handbook of Phisiology, Sec. 7. Vol. V. (Hamilton, D. W. and R. O. Greep, eds.) 339-351. Amer. Physiol. Soc. Washington, D. C. 1975.

17) Gwatkin, R. B. L., Fertilization Mechanisms in Man and Mammals. Plenum Press. New York 
1977.

18) Zaneveld, L. J. D., Proc. IVth Eur. Steril. Congr., 21-29. 1978.

19) Yanagimachi, R., in Immunobiology of Gametes. (Edidin, M. and M. H. Johnson, eds.) 255-289. Cambridge Univ. Press. Cambridge. 1977.

20) Yanagimachi, R, in Fertilization and Embryonic Development in Vitro. (Mastrolanni, L., JR. and J. D. Biggers, eds.) 81-182. Plenum Press. New York. 1981.

21） 入谷 明, 遗伝, 27 (11)：33-40. 1973.

22）岩松婜司，生物科学，25：215-224。1973.

23）豐田 裕，化学々生物，12：446-455，1974.

24）野田善郎，代謝，11：1563-1571. 1976.

25） 入谷 明，日畜会報，48：445-452. 1977 .

26）入谷 明, 代謝, 16:651-659. 1979.

27) Yanagimachi, R., in Current Topics in Developmental Biology, Vol. 12. (Moscona, A. A. and A. Monroy, eds.) 83-105. Academic Press. New York. 1978.

28) Meizel, S., in Development in Mammals 3. (Martin, H. J., ed.) 1-64. North-Holland Publishing Company. Amsterdam. 1978.

29) Green, D. P. L., in Development in Mammals 3. (Martin, H. J., ed.) 65-81. North-Holland Publishing Company. Amsterdam. 1978.

30）柳町隆造，岩松腕司，科学，44：293-299. 1974.

31）豊田 裕, 实験生殖生理学の展開一動物モデルの 視点加与。第1版，鈴木善社編，25-36。・フト サイエンス社. 東京. 1982 .

32) Chang, M. C., J.Anim. Sei., 27 (Suppl. 1): 15 22. 1968.

33) BRACKETT, B. G., in Advances in the Biosciences, Vol. 4. (RAspé, G., ed.) 73-94. Pergamon Press. Vieweg. 1970.

34) Brackett, B.G., in The Biology of the Blastocyst. (Blandau, R. J., ed.) 329-348. Univ. of Chicago Press. Chicago. 1971.

35) Chang, M. C., in The Functional Anatomy of the Spermatozoon. (Afzelius, B. A., ed.) 97-103. Pergamon Press. New York. 1974.

36) Chang, M. C., in Regulation of Growth and Differentiated Function in Eukaryote Cells. (TAwler, G. P., ed.) 499-507. Raven Press, Publishers. New York. 1975.

37) Rogers, B. J., Gamete Res., 1: 165-223. 1978.

38) Bracketт, B. G., in BARC, Symposium No. 3 Animal Reproduction. (HAwK, H., ed.) 171-193. Allanheld. Osnun. Montclair. 1979.

39) Blandau, R. J., Fertil. Steril., 33: 3-11. 1980.

40) Wright, R. W., JR. and K. R. Bondioli, J. Anim. Sci., 53: 702-729. 1981.

41) Soupart, P., in Bioregulators of Reproduction. (JAGIELLO, G, and H. J. VOGEL, eds.) 427-457. Academic Press. New York. 1981.
42) Rogers, B. J., in Bioregulators of Reproduction. (Jagiello, G. and H. J. Vogel, eds.) 459-486. Academic Press. New York. 1981.

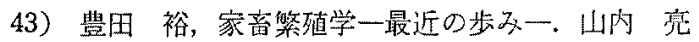
編.153-172. 文永堂. 東京. 1978.

44) Gould, K. G., Feder. Proc., 32: 2069-2074. 1973.

45) Brackett, B. G., Environmental Health Perspectives, 24: 65-71. 1978.

46) Bavister, B. D., in Fertilization and Embryonic Development in Vitro. (Mastrolanni, L., Jr, and J. D. Biggers, eds.) 41-60. Plenum Press. New York. 1981.

47) Bavister, B. D., in In Vitro Fertilization and Embryo Transfer. (Hafez, E. S. E. and K. SeMM, eds.) 13-29. MTP Press Lim. Lancaster. 1982.

48) Barros, C. and J. Leal, in In Vitro Fertilization and Embryo Transfer, (HAFEz, E. S. E. and K. SemM, eds.) 37-49. MTP Press Lim. Lancaster. 1982.

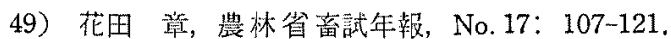
1971.

50）豊田 裕, 家望繁殖誌，19(5)：11-20. 1973.

51）豊囦 裕, 璂伝, 27(11)：41-47, 1973.

52) 暟国 裕, 代竘, 16:713-721。 1979.

53）丹羽晧二・三宅正史・入谷 明・西川㱛正，ホル モンと瀶床, 24: 663-669. 1976.

54）丹羽晊二・入谷 明・先天異常，21：53-64. 1981.

55）丹羽晧二，哺舀動物の初期発生一基礎理論上実験 法一. 林尾左知丸他編. 191-209，211-213. 理工 学社. 東京. 1981 .

56）福井豊・金川弘司，畜産の研究，35：11-17. 1981.

57) Bedford, J. M., in Methods in Mammalian Embryology. (Daniel, J. C., JR., ed.) 37-63. W. H. Freeman and Co. San Francisco. 1971.

58) Thibault, C. and L. Dauzier, Ann. Biol. Anim. Biochim. Biophys., 1: 277-294. 1961.

59) Bedford, J. M. and M. C. Chang, Nature, 193: 898-899. 1962.

60) Suzuki, S. and L. Mastroianni, Am. J. Obstet. Gynecol., 93: 465-471. 1965.

61) Brackett, B. G. and W. L. Williams, J. Exp. Zool., 160: 271-282. 1965.

62) Seit $Z$, H. M., B. G. Brackett and L. MastroianNI, Biol. Reprod., 2: 262-267. 1970.

63) Seit z, H. M., G. Rocha, R. G. Brackett and L. Mastroianni, Fertil. Steril., 21: 325-328. 1970.

64) Dandekar, P. and L. R. Fraser, J. Reprod. Fertil., 46: 77-81. 1976.

65) Dauzier, L. and C. Thibault, Proc. III id Int. Congr. Anim. Reprod. A. I., Cambridge, Sec. I: 58-61. 1956.

66) Bedford, J. M., J. Reprod. Fertil., Suppl. 2: $35-$ 48. 1967.

67) Chang, M. C., A. Hanada and D. M. Hunt, 
Nature, 232: 343-344. 1971.

68) Kirton, K. T. and H. D. Hafs, Science, 150: 618-619. 1965.

69) Ericsson, R. J., Nature, 221: 568-569. 1969.

70) Johnson, W. L. and A. G. Hunter, Biol. Reprod., 7: 332-340. 1972.

71) Rosado, A., J. J. Hicks, A. Reyes and I. Blanco, Fertil. Steril., 25: 821-824. 1974.

72) Ericsson, R. J., D. A. Buthala and J. F. Norland, Science, 173: 54-55. 1971.

73) Brackett, B. G., J. A. Mills, G. Oliphant, H. M. Seitz, G. G. Jeitles and L. Mastrolanni, Int. J. Fertil., 17: 86-92. 1972.

74) Ogawa, S., K. Satoh, M. Hamada and H. Hashiмото, Nature, 238: 270-271. 1972.

75）SATo,K., 日不娃会誌，26：243-246. 1981.

76) Sato, K., M. Kimura and Y. Sakuma, 日不妊会 诘, 27: 302-305. 1982.

77）冲永洋子, 日不妊会誌，17：107-122. 1972.

78）Kubo, H., 日不娃会誌，22：78-85. 1977.

79) Reyes, A., B. Golcoechea and A. Rosado, Fertil. Steril., 29: 451-455. 1978.

80) Brackett, B. G. and G. Oliphant, Biol. Reprod., 12: 260-274. 1975.

81) Brackett, B. G., J. L. Hál and Y. K. Oh, Fertil. Steril., 29: 571-582. 1978.

82) Akruk, S. R., W. J. Humphreys and W.L. WilLIAMS, Differentiation, 13: 125-131. 1979.

83) Olnphant, G., Fertil. Steril,, 27: 28-38. 1976.

84) Oliphant, G. and C. A. Singhas, Biol. Reprod., 21: 937-944. 1979.

85) Oliphant, G. and B. G. Brackett, Biol. Reprod., 9: 404-414, 1973.

86) Virtyapanich, P. and J. M. Bedford, J. Exp. Zool., 216: 169-174. 1981.

87) Akruk, S. R., A. A. Farooqui, W. L. Williams and P. N. Srivastaya, Gamete Res., 2: 1-13. 1979.

88) Hosor, Y., K. Niwa, S. Hatanaka and A. Iritani, Biol. Reprod., 24: 637-642. 1981.

89) Niwa, K., Y. Hosor, K. ÖHaRA and A. Iritani, Anim. Reprod. Sci., submitted.

90) Brackett, B. G. and W. L. Williams, Fertil. Steril., 19: 144-155. 1968.

91) Brackett, B. G., Fertil. Steril., 20: 127-142. 1969.

92) Fraser, L. R., P. Dandekar and R. Vaidya, Biol. Reprod., 4: 229-233. 1971.

93) Brackett, B. G., J. A. Mills and G. G. Jeitles, Fertil. Steril., 23: 898-909. 1972.

94) Fraser, L. R. and P. V. Dandekar, J. Reprod. Fertil., 33: 159-161. 1973.

95) Brackett, B. G., D. E. Killen and M. D. Peace, Fertil. Steril., 22: 816-828. 1971.

96) Lambert, R. D., L. G. Blanchett and M. TouriGNY, Anim. Reprod. Sci., 1: 43-47. 1978.
97) Bracketr, B. G. and J. B. Server, Fertil. Steril., 21: $687-695.1970$.

98) Harrison, R. M. and W. R. Dukelow, J. Reprod. Fertil., 31: 483-486. 1972.

99) Suzuki, S. and L. Mastroianni, Fertil. Steril., 19: 716-725. 1968.

100) Trotnow, S., S. Al-Hasani and C. Sadtler, Arch. Gynecol., 231: 41-50. 1981.

101) Mills, J. A., G. G. Jeitles, Jr. and B. G. BrackETT, Fertil. Steril., 24: 602-608. 1973.

102) Fraser, L. R. and P. V. Dandekar, J. Exp. Zool., 184: 303-312, 1973.

103) Seidel, G. E., R. A. Bowen and M. T. Kane, Fertil. Steril., 27: 861-870. 1976.

104) Fraser, L. R., G. R. Paton and R. D. Barnes, J. Reprod. Fertil., 43: 531-534. 1975.

105) Yanagimachi, R, and M. C. Chang, Nature, 200: 281-282. 1963.

106) Yanagimachi, R. and M. C. Chang, J. Exp. Zool., 156: 361-376. 1964.

107) Yanagimachi, R., J. Reprod. Fertil., 18: 275-286. 1969.

108) Bavister, B. D., R. YanAgimachi and R. J. TeichMAN, Biol. Reprod., 14: 219-221. 1976.

109) Bavister, B. D., J. Reprod. Fertil, 38: 431-440. 1974.

110) Bayister, B. D. and R. Yanagimachi, Biol. Reprod., 16: 228-237. 1977.

111) Barros, C. and C. R. Austin, J. Exp. Zool., 166: 317-323. 1967.

112) Gwatkin, R. B. L. and O.F. Andersen, Nature, 224: 1111-1112. 1969.

113) Yanagmachi, R., J. Exp. Zool., 170：269-280. 1969.

114) Miyamoto, H. and M.C. Chang, J. Reprod. Fertil., 30: 309-312. 1972.

115) Yanagimachi, R., Biol. Reprod., 3: 147-153. 1970.

116) Barros, C. and A. Garavagno, J. Reprod. Fertil., 22: 381-384. 1970.

117) Miyamoto, H. and M.C. Chang, J. Reprod. Fertil., 33: 481-487. 1973.

118) Miyamoto, H., Y. Toyoda and M. C. Chang, Biol. Reprod., 10: 487-493. 1974.

119) Imamatsu, T. and M. C. Chang, J. Exp. Zool., 182: 211-216. 1972.

120) Barros, C., J. Reprod. Fertil., 17: 203-206. 1968.

121) Gwatkin, R. B. L., O. F. Andersen and C. F. Hutchinson, J. Reprod. Fertil., 30: 389-394. 1972.

122) Toyoda, Y. and M. C. Chang, J. Reprod. Fertil., 36: 9-22, 1974.

123) Niwa, K., H. Imai, C. I. Kim and A. Iritani, J. Reprod. Fertil., 58: 109-114. 1980.

124) Bavister, B. D., J. Reprod. Fertil., 18: 544-545. 1969. 
125) Bavister, B. D., J. Reprod. Fertil., 35: 161-163. 1973.

126) Yanagimachi, R., J. Reprod. Fertil., 23: 193196. 1970.

127) Lui, C. W., L. E. Cornett and S. Meizel, Biol. Reprod., 17: 34-41. 1977.

128) Bavister, B. D., Proc. 8 th Ann. Meet. Soc. Study Reprod., p. 63. 1975.

129) Hanada, A. and M. C. Chang, J. Reprod. Fertil., 46: 105-114. 1976.

130) Bayister, B. D., B. J. Rogers and R. Yanagiмасн1, Biol. Reprod., 19: 358-363. 1978.

131) Bavister, B. D., J. Reprod. Fertil., 43: 363-366. 1975.

132) Cornett, L. E. and S. Meizel, Proc. Natl. Acad. Sci. U. S. A., 75: 4954-4958. 1978.

133) Bayister, B. D., A. F. Chen and P.C. Fu, J. Reprod. Fertil., 56: 507-513, 1979.

134) Cornetr, L. E., B. D. Bayister and S. Meizel, Biol. Reprod, 20: 925-929. 1979.

135) Meizel, S., C. W. Lui, P. K. Working and R. J. MrSny, Dev. Growth Diff., 22: 483-494. 1980.

136) Mrsny, R. J., L. Waxman and S. Meizel, J. Exp. Zool., 210: 123-128. 1979.

137) Leibfried, M. L. and B. D. Bavister, Gamete Res., 4: 57-63. 1981.

138) Yanagimachi, R, in In Vitro Fertilization and Embryo Transfer. (Hafez, E. S. E. and K. SEMM, eds. ) 65-76. MTP Press Lim. Lancaster. 1982.

139) Yanagimachi, R., Biol. Reprod., 19: 949-958. 1978.

140) Yanagimachi, R., Gamete Res., 5: 323-344. 1982.

141) Mahi, C. A. and R. Yanagimachi, J. Reprod. Fertil., 35: 55-66. 1973.

142) Talbot, P., L. E. Franklin and E. M. Fussell, J. Reprod. Fertil., 36: 429-432. 1974.

143) Tsunoda, Y. and M. C. Chanc, J. Exp. Zool., 201: 445-456. 1977.

144) Bayister, B. D., J. Exp. Zool., 210: 259-264. 1979.

145) Morton, B., B. J. Rogers and T.S. K. Chang, Biol. Reprod., 9: 356-360. 1973.

146) Morton, B. and L. Albagli, Biochem. Biophys. Res. Comm., 50: 697-705. 1973.

147) Morton, B. and T.S. K. Chang, J. Reprod. Fertil., 35: 255-263. 1973.

148) Rogers, B. J. and B. Morton, J. Reprod. Fertil,, 35: $477-487.1973$.

149) Rogers, B. J. and B. Morton, Biol. Reprod., 9: 361-369. 1973.

150) Imai, H., K. Niwa and A. Iritani, J. Exp. Zool., 220: 261-265. 1982.

151) Dravland, E. and S. Meizel, Gamete Res., 4:
515-523. 1981.

152) Hirao, Y. and R. Yanagimachi, J. Exp. Zool., 206: 365-369. 1978.

153) Whittingham, D. G. and B. D. Bayister, J. Reprod. Fertil., 38: 489-492. 1974.

154) Yanagmachr, R., J. Reprod. Fertil., 28: 477480. 1972.

155) Hanada, A. and M.C. Chang, Biol. Reprod., 6: 300-309. 1972.

156）花四 管, 家畜繁殖誌, 27：123-125. 1981.

157) Tsunoda, Y., T. A. Parkening and M. C. Chang, Experientia, 32: 223-224. 1976.

158) Parkening, T. A. and M. C. Chang, Biol. Reprod., 17: 527-531. 1977.

159) Yanagimachi, R., A. Lopate, C. B. Odom, R. A. Bronson, C. A. MaHi and G. L. Nicolson, Fertil. Steril., 31: 562-574. 1979.

160) Whittingham, D. G., Nature, 220: 592-593. 1968.

161) Iwamatsu, T. and M. C. Chang, Nature, 224: 919 920. 1969.

162) Imamatsu, T. and M. C. Chang, J. Exp. Zool., 175: 271-281. 1970.

163）豊田 裕・横山案介・星冬四郎，家音繁殖誌，16： 147-151. 1971.

164）豊田 裕・横山峯介・星冬匹郎，家音繁殖誌，16： 152-157. 1971.

165) Miyamoto, H. and M.C. Chang, J. Reprod. Fertil., 32: 193-205. 1973.

166) Hoppe, P. C. and W. K. Whitten, J. Reprod. Fertil., 39: 433-436. 1974.

167）岡本正則・豊田 裕，日音会報，51：171-177. 1980.

168) Hoppe, P. C., Biol. Reprod., 15: 39-45. 1976.

169) Fraser, L. R, and P. J. Quinn, J. Reprod. Fertil., 61: 25-35. 1981 .

170) 青沼 㢣・阙部 勝・河合裕一, 薬学雑誌, 96: 1307-1312. 1976.

171) Aonuma, S., M. Okabe and M. Kawaguchi, J. Reprod. Fertil., 53: 179-183. 1978.

172) Aonuma, S., M. OKäe, M. Kawaguchi and $Y$. Kishi, J. Reprod. Fertil., 63：463-466. 1981.

173) Iwamatsu, T, and M. C. Chang, J. Reprod. Fertil., 26: 197-208. 1971.

174) Heffner, L. J., P. M. Saling and B. T. Storey, J. Exp. Zool., 212: 53-59. 1980.

175) Heffner, L. J. and B. T. Storey, J. Exp. Zool., 218: $427-434.1981$.

176) Saling, P. M., B. T. Storey and D. P. Wolf, Devel. Biol., 65: 515-525. 1978.

177) Miyamoto, $H$. and T. Ishibashi, J. Reprod. Fertil., 45: 523-526. 1975.

178) Inour, M. and D. P. Wolf, Biol. Reprod., 13: 340-346. 1975.

179) Wolf, D. P. M. Inove and R. A. Stark, Biol. 
Reprod., 15: 213-221. 1976.

180) Oliphant, G. and B. G. Brackett, Fertil. Steril., 24: 948-955. 1973.

181) Fraser, L. R., J. Reprod. Fertil., 62: 63-72. 1981.

182) Fraser, L. R., J. Reprod. Fertil., 57: 377-384. 1979.

183) Gwatkin, R. B. L., O. F. Andersen and D. T. Williams., J. Reprod. Fertil., 41: 253-256. 1974.

184) Chang, M. C., Nature, 179: 258-259. 1957.

185) Weinman, D. F. and W. L. Williams, Nature, 203: 423-424. 1964.

186) Davis, B. K., J. Reprod. Fertil., 41: 241-244. 1974.

187) Hoppe, P. C., J. Exp. Zool., 192：219-222. 1975

188) Cross, P. C. and R. L. Brinster, Biol. Reprod., 3: 298-307. 1970 .

189) Miqamoto, H. and M. C. Chang, J. Reprod. Fertil., 30: 135-137. 1972.

190) Pavlok, A. and A. McLaren, J. Reprod. Fertil., 29: 91-97. 1972.

191) Hoppe, P. C. and S. Pitts, Biol. Reprod., 8: 420426. 1973.

192) Hoppe, P. C. and W. K. Whitten, J. Exp. Zool., 188: 133-136. 1974.

193）福田芳詔・岡田修・豐田裕, 家畜繁殖誌, 18： 73-77. 1972.

194) Tsunoda, Y. and M. C. Chang, J. Reprod. Fertil., 44: 139-142. 1975.

195) Fraser, L. R. and L. M. Drury, Biol. Reprod., 13: 513-518. 1975.

196) Thadani, V. M., J. Exp. Zool,, 219: 277283. 1982.

197) Wolf, D.P. and M. Inoue, J.Exp. Zool., 196: 27-38. 1976.

198) Furuda, Y, and M. C. Chang, Arch. Androl., 1: 267-273. 1978

199) Stanger, J. D. and P. Quinn, Gamete Res., 5: 61-70. 1982.

200) Fraser, L. R. and I. Maudlin, J. Reprod. Fertil., 52: 103-106. 1978.

201) Fraser, L. R. and L. M. Drury, J. Exp. Zool,, 197: 13-20. 1976.

202) Fraser, L. R., J. Reprod. Fertil., 49: 83-87. 1977.

203) Hoppe, P. C., Gamete Res., 3: 343-349. 1980.

204) Kasai, K., Y. Minato and Y. TOYODA, 家蓄繁殖 誌, 24：19-22. 1978.

205) Parkening, T. A. and M. C. Chang, Biol. Reprod., 15: 647-653. 1976.

206) Kaleta, E., J. Reprod. Fertil., 51: 375-381. 1977.

207) Niwa, K., M. Araki and A. Iritant, Biol. 22: 1155-1159. 1980.

208) Muknerjee, A. B., Nature, 237: 397-398. 1972.

209) Iwamatsu, T. and M. C. Chang, J. Reprod. Fertil., 31: 237-247. 1972.
210) Binor, Z. and D. P. WoLf, J. Reprod. Fertil., 56: 309-314. 1979.

211) 豐田裕・福田若詔, 音座の研究, 29：1373-1377. 1975.

212) Fraser, L. R., J. Reprod. Fertil., 55：153-160. 1979.

213) Wolf, D. P. and M. Hamada, J. Reprod, Fertil., 48: 213-214. 1976.

214) Parkening, T.A. and M. C. Chang, J. Reprod. Fertil., 48: 381-383. 1976.

215) Tsunoda, Y. and M. C. Chang, J. Exp. Zool, 193: 79-86. 1975.

216) Parkening, T. A., Y. Tsunoda and M. C. Chang, J. Exp. Zool., 197: 369-374. 1976.

217) Mukherjee, A. B. and M. M. Cohen, Nature, 228: $472-473$. 1970 .

218) KasAI, K., M. Sugrmoto and Y. ToyodA, 日蓄会 報，50：885-890. 1979 .

219) Fraser, L. R., H. M. Zanellotti and G. R. PA. TON, Nature, 260: 39-40. 1976.

220) Maudlin, I. and L. R. Fraser, J. Reprod. Fertil., 50: 275-280. 1977.

221) Fraser, L. R. and I. Maudlin, Environ. Health Perspec., 31: 141-149. 1979.

222) Maudlin, I. and L. R. Fraser, J. Reprod. Fertil., 52: 107-112. 1978.

223) Pickworth, S. and M. C. Chang, J. Reprod. Fertil., 19: 371-374. 1969.

224) Pickworth, S., G. Yerganian and M. C. Chang, Anat. Rec., 162: 197-208. 1968.

225) Hamner, C. E., L. L. Jennings and N. J. Sojka, J. Reprod. Fertil., 23: 477-480. 1970.

226) Biggers, J. D., W. K. Whitten and D. G. Whit IINGHAM, in Methods in Mrmmalian Embryology. (Danier, J.C., Jr., ed.) 86-116. W. H. Freeman and Co. San Francisco. 1971.

227) Bowen, R. A., Biol. Reprod., 17: 144-147. 1977.

228) Noske, I. G., Experientia, 28: 1348-1350. 1972.

229) Hanada, A. and M. C. Chang, J. Exp. Zool., 203: 277-286. 1978.

230) Yanagimachi, R., Anat. Rec., 174: 9-20. 1972.

231) Yanagimachi, R., J. Reprod. Fertil., 38：485 488. 1974.

232) Noda, Y. D. and R. Yanagmachi, Devel. Growth Diff., 18: 15-23. 1976.

233) Yanagimachi, R. and N. Usui, Exp. Cell Res., 89: 161-174. 1974.

234) Fleming, A. D. and R. Yanagimachi, Gamete Res., 4: 253-273. 1981.

235) Fleming, A. D., N. S. Kosower and R. YANAGIMACHI, Gamete Res., 5: 19-33. 1982.

236) Hung, T. T.F., A. D. FlEMING and R. YANAGIMACHI, J. Exp. Zool,, 217: 287-290. 1981.

237) Fleming, A. D. and R. Yanagimachi, J. Exp. Zool., 220: 109-115. 1982. 
238) Saling, P. M. and B. T. Storey, J. Cell Biol., 83: 544-555. 1979.

239) Saling, P. M., J. Sowinski and B. T. Storey., J. Exp. Zool., 209: 229-238. 1979.

240) Phillips, D. M. and R. M. Shalgi, J. Exp. Zool., 213: 1-8. 1980.

241) Hyne, R. V. and D. L. Garbers, Biol. Reprod., 24: 257-266. 1981.

242) Rogers, B. J. and R. Yanagimachi, Biol. Reprod., 13: 568-575. 1975.

243) Rogers, B. J., M. Ueno and R. Yanagimachi, Biol. Reprod., 25: 639-648. 1981.

244) Yanagimachi, R., Biol. Reprod., 13: 519-526. 1975.

245) Talbot, P., R. G. Summers, B. L. Hylander, E. M. Keough and L. E. Frankiln, J. Exp. Zool., 198: 383-392. 1976.

246) Green, D. P. L., J. Cell Sci., 32: 137-151. 1978.

247) Singh, J.P., D. F. Babcock and H. A. Lardy, Biol. Reprod., 22: 566-570. 1980.

248) Santos-SacchI, J, and M. Gordon, J. Cell Biol., 85: 798-803. 1980.

249) Rogers, B. J. and R. Yanagimachi, Biol. Reprod. 15: 614-619. 1976.

250) Quigley, M. M., in In Vitro Fertilization and Embryo Transfer. (Hafez, E.S.E. and K. SEMM, eds.) 77-88. MTP Press Lim. Lancaster. 1982.

251) Toyoda, Y. and M. C. Chang, Nature, 220:589591. 1968.

252) Mryamoto, H. and M.C.Chang, Nature, 241: 50-51. 1973.

253) Miyamoto, H. and M.C.Chang, Biol. Reprod., 9: 384-393. 1973.

254) Toyoda, Y. and M. C. Chang, J. Reprod. Fertil., 36: 125-134. 1974.

255) Shalgi, R., N. Dekel and P.F. Kraicer, J. Reprod. Fertil., 55: 429-435. 1979.

256) Kaplan, R. and P. F. Kraicer, Gamete Res., 1: 281-285. 1978.

257) Quigley, M. M., Arch. Androl., 5: 65-66. 1980

258) Niwa, K. and M. C. Chang, Biol. Reprod., 11: 463-469. 1974.

259) Niwa, K. and M. C. Chang, J. Reprod. Fertil., 35: 577-580. 1973.

260) Niwa, K., M. Mryake, A. Iritani and Y. NishiKAWA, J. Reprod. Fertil., 47: 105-106. 1976.

261) Niwa, K. and M. C. Chang, J. Exp. Zool., 189: 353-356. 1974

262) Nishimura, H., K. Niwa, M. Mirake and A. IrITANI, J. Exp. Zool., 223: 115-119. 1982.

263) Niwa, K. and M. C. Chang, J. Reprod. Fertil,, 40: 471-474. 1974.

264) Niwa, K. and M. C. Chang, Fertil. Steril., 26: 1266-1272. 1975 .
265）宮本 元・石橋武彦，日畜会報，46：226-229. 1975.

266) Davis, B. K., Proc. Soc. Exp. Biol. MED., 151: 240-243. 1976.

267) Miұamoto, H. and T. Ishibashi, J. Reprod. Fertil., 45: 523-526. 1975.

268) Davis, B. K., Proc. Soc. Exp. Biol. Med., 157: 54-56. 1978.

269) Niwa, K. and A. Iritani, J. Reprod. Fertil., 53: 267-271. 1978.

270) Niwa, K. and M. C. Chang, Biol. Reprod., 13: 187-189. 1975.

271) Niwa, K. and M. C. Chang, J. Reprod. Fertil., 43: 435-451. 1975.

272）丹羽晧二，三宅正史，入谷 明，西川義正，日蓄 会報，47：654-658. 1976.

273) Niwa, K., M. Miyake, A. Iritani and Y. NishiKAWA, J. Reprod. Fertil., 47: 105-106. 1976.

274) NiWA, K. and M. C. Chang, J. Reprod. Fertil., 44: 305-308. 1974.

275) Kasai, M., A. Iritani and M. C. Chang, Biol. Reprod., 21: 839-844. 1979.

276） NiwA, K., M. Kasai and A. Iritani, 日蓄会報, 50: 747-752. 1979.

277）三宅正史・丹羽晧二・入谷 明，日畜会報，49: 739-744. 1978.

278) Dukelow, W. R., in Non-Human Primate models for Study of Human Reproduction. (Kumar, T. C. A., ed.) 88-98. S. Karger. Basel. Switzerland. 1980.

279) Gould, K. G., E. M. Cline and W. L. Williams, Fertil. Steril., 24: 260-268. 1973.

280) Kuehl, T. J. and W. R. Dukelow, J. Med. Primatol., 4: 209-216. 1975.

281) Kuehl, T. J. and W. R. Dukelow, Biol. Reprod., 21: 545-556. 1979.

282) Asakawa, T. and W. R. Dukelow, Biol. Reprod., 26: $579-583,1982$

283) Kuehl, T. J. and W. R. Dukelow, J. Reprod. Fertil., 64: 135-137. 1982.

284) Hancock, J. L. and I. W. Rowlands, Vet. Rec., 61: 771-776. 1949

285) Van Der Stricht, O., Arch. Biol., Paris, 33: 229-300. 1923. (文献 276 上り引用)

286) Phemister, R. D., P. A. Holst, J. S. Spano and M. L. Hopwood, Biol. Reprod., 8： 74-82. 1973.

287) Mahi, C. A. and R. Yanagimáchi, J. Exp. Zool., 196: 189-196. 1976.

288) Mahi, C. A. and R. Yanagimachi, Gamete Res., 1: 101-109. 1978

289) Fukuda, Y., M. B. Maddock and M. C. Chang, J. Exp. Zool., 207: 481-490. 1979.

290) Dauzier, L. and C. Thibault, Compt. Rend. Acad. Sci., 248: 2655-2656. 1959. (文献 38 上り 引用). 
291) Kraemer, D. C., Ph. D. Thesis, Texas Univ. 1966. (Thibault, C., in Fertilization, Vol. II, p. 405-435. 1969. および文献 40 よりる用).

292) Bondroli, K. R. and R. W. Wright, JK., J. Anim. Sci., 51: 660-667. 1980.

293) Shams-Borhan, G. and R. A. P. Harrison, Gamete Res., 4: 407-432. 1981.

294) Harms, V.E. and D. Smidt, Ber. Münch. Tierärztl. Wochenschr., 83: 269-275. 1970.

295) MEYer, J. N. and D. SMIdT, Ber. Münch. Tierärztl. Wochenschr., 86: 104-106. 1973.

296) Baker, R. D. and C. Polge, Can. J. Anim. Sci., 56: 105-119. 1976.

297) Iritani, A., E. Sato and Y. Nishikawa, 日不妊会 誌, 20：404-409. 1975.

298) Iritani, A., K. Niwa and H. Imai, J. Reprod. Fertil., 54: 379-383. 1978.

299) Imai, H., K. Niwa and A. IRItani, J.Reprod. Fertil, 51: 495-497. 1977.

300) Imai, H., K. Niwa and A. Iritani, J. Reprod. Fertil., 56: 489-492. 1979.

301) Imai, H., K. Niwa and A. IRItani, Biol. Reprod., 23: 481-486. 1980.

302) Pavlok, A., Int. J. Fertil., 26: 101-106. 1981.

303) Hanada, A. and H. NAGAse, 象畜䋈殖融, 27: 113-118. 1981.

304) Sreenan, J., J. Agr. Sci., 75: 393-396. 1970.

305) Von Bregulla, K., U. Gerlach and R. Hahn, Dtsch. Tierärztl. Wochenschr., 81: 465-470. 1974.

306) Iritani, A. and K. Niwa, J. Reprod. Fertil,, 50: 119-121. 1977.

307) Brackett, B. G., Y. K. Оh, J. F. Evans and W. J. DONAWICK, Theriogenology, 9: 89. 1978.

308) Brackett, B. G., J. F. Evans, W. J. Donawick, M. L. Borce and M. A. Cofone, Arch. Androl., 5: 69-71. 1980.

309) Brackett, B. G., Y. K. OH, J. F. Evans and W. J. Donawick, Biol. Reprod., 23: 189-205. 1980.

310) Bracketr, B. G., D. Bousquet, M. L. Borce, W. J. Donawick, J. F. Evans and M. A. Dressel, Biol. Reprod., 27; 147-158. 1982.

311) Fulka, J., Jr., A. Pavlok and J. Fulka, J. Reprod. Fertil, 64: 495-499. 1982.

312) Lorton, S. P. and N. L. First, Biol. Reprod.. 21: 301-308. 1979.

313) Calcote, R. D., Diss. Abstr. Int., 40B: 2646B. 1979.

314) Brackett, B. G., M. A. Cofone, M. L. Bolce and D. Bousquest, Gamete Res., 5: 217 227. 1982.

315) Bousquet, D. and B. G. Brackett, Theriogenology, 17: 199-213. 1982.

316) Kim, C. I., K. Niwa, H. Imai and A. Iritani, J. Exp. Zool., 213: 181-183. 1980.

317) KIM, C. I., 学位論文, 宗都大学。 1981 .
318) Edwards, R. G., B. D. Bavister and P.C. Ste ptoE, Nature, 221: 632-635. 1969.

319) Seitz, H. M., G. Rocha, B. G. Brackett and L. Mastroianni, Fertil. Steril., 22: 255-262. 1971.

320) Bavister, B. D., R. G. Edwards and P.C. Steptoe, J. Reprod. Fertil., 20: 159-160, 1969.

321) Soupart, P. and P. A. Strong, Fertil. Steril, 25: 11-44. 1974 ,

322) Soupart, P. and L. L. Morgenstern, Fertil. Steril., 24 : 462-478. 1973.

323）久保春海, 日不妊会読，22：182-190. 1977 ,

324) Edwards, R. G., P. C. Steptoe and J. M. Purdy, Nature, 227: 1307-1309. 1970.

325) Lopata, A., R. Mcmaster, J.C. Mcbain and W. I. H. Johnston, J. Reprod. Fertil., 52: 339-342. 1978.

326) Jacobson, C. B., J. G. Sites and L. F. Arias-Be RNAL, Int. J. Fertil., 15: 103-114. 1970.

327) McMaster, R., R. Yanagimachi and A. Lopata, Biol. Reprod., 19: 212-216. 1978.

328) Nishtmoto, T., I. Yamada, K. Niwa, T. Mort, T. Nishimura and A. Iritani, J. Reprod. Fertil., 64: 115-119. 1982.

329) Steptoe, P.C. and R. G. Edwards, Lancet, 2: 366. 1978.

330) Steptoe, P. C., R. G. Edwards and J. M. Purdy, Br. J. Obstet. Gynaecol., 87: 757-768. 1980.

331 Enwards, R.G., P. C. Steptoe and J. M. Purdy, Br. J. Obstet. Gynaecol, 87: 737-756. 1980.

332) Lopata, A., W. I. H. Johnson, I. J. Hoult and A. L. Spiers, Fertil. Steril., 33: 117-120. 1980.

333) Johnston, I., A. Lopata, A. Spiers, I. Hoult, G. Kellow and Y. Duplessis, Fertil. Steril., 36: 699-706. 1981.

334) Trounson, A. O., J. F. Leeton, C. Wood, J. Webb and J. Wood, Science, 212: 681-682. 1981.

335) Wood, C., A. Trounson, J. Leeton, J. McTalbot, B. Buttery, J. WeBb, J. WOOD and D. Jessup, Fertil. Steril., 35: 502-508, 1981.

336) Feichtinger, W., S. Szalay, P. Kemeter, A. Beck and H. JANisCh, Geburtsh. Frauenheilk., 42: 197-199, 1982.

337) Schlesselman, J. J., Am. J. Obstet. Gynecol. . 135: 135-148. 1979.

338) Evans, M. I. and A. O. Dixler, J. Am. Med. Assoc., 245: 2324-2327. 1981.

339) Trefel, H. O., J.Am. Med. Assoc, 247: 32353242, 1982.

340) Yanagimachi, R., H. Yanagimachi and B. J.RoGERS, Biol. Reprod., 15: 471-476. 1976.

341) Rogers, B. J., H. Van Campen, M. Ueno, H. Lam * Bert, R. Bronson and R. Hale, Fertil. Steril.. 32: 664-670. 1979 .

342) Karp,L. E., R. A. Williamson, D. E. Moore, K. K. Shy, S. R. Plymate and W. D. Smith, Obstet. 
Gynecol., 57: 620-623. 1981.

343) Hall, J. L., Fertil. Steril., 35: 457-463. 1981.

344) Stencheyer, M. A., L. R. Spadoni, W. D. Smith, L. E. Karp, K. K. Shy, D. E. Moore and R. BE RGER, Am. J. Obstet. Gynecol., 143: 91-94. 1982.

345) Kanwar, K. C., R. Yanagimachi and A. Lopata, Fertil. Steril., 31: 321-327. 1979.

346) Menge, A. C. and C. S. BlaCK, Fertil. Steril., 32: 214-218. 1979.

347) Overstrett, J. W., R. Yafagimachi, D. F. Katz, K. Hayashi and F. W. Hanson, Fertil. Steril., 33: 534-542. 1980.

348) HaAs, G. G., Jr., J. E. Sokoloski and D. P. Wolf,
Am. J. Reprod. Immunol., 1: 40-43, 1980.

349) Pryor, J. P., W. P. Collins, G. Landon and J. P. P. TYLER, Br. J. Urol., 53: 660-663. 1981.

350) Cohen, J., P. Felten and G. H. Zeilmaker, Fertil. Steril., 36: 356-362. 1981.

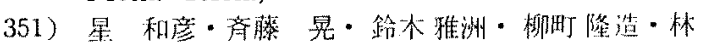
恵子, 月不妊会誌，27：306-312. 1982.

352) Fleming, A. D., R. Yanagimachi and H. YanagrMACHI, Gamete Res., 2: 357-366. 1979.

353) Quin, P., J. Exp. Zool., 210: 497-506. 1979.

354) PavLok, A., Folia Biol., 26: 188-193. 1980.

355) Overstreet, J. W. and W. C. Hembree, Fertil. Steril., 27: 815-831. 1976. 